\title{
Article \\ Roof Hydraulic Fracturing for Preventing Floor Water Inrush under Multi Aquifers and Mining Disturbance: A Case Study
}

\author{
Pengpeng Wang ${ }^{1,2, *(1)}$, Yaodong Jiang ${ }^{3}$ and Qingshan Ren ${ }^{1}$ \\ 1 School of Energy and Mining Engineering, China University of Mining and Technology (Beijing), \\ Beijing 100083, China; bqt1900101024@student.cumtb.edu.cn \\ 2 Institute of Intelligent Manufacturing and Intelligent Mining, Yuncheng Vocational and Technical University, \\ Yuncheng 054000, China \\ 3 School of Mechanics and Civil Engineering, China University of Mining and Technology (Beijing), \\ Beijing 100083, China; jiangyd@cumtb.edu.cn \\ * Correspondence: bqt1800101025@student.cumtb.edu.cn
}

check for updates

Citation: Wang, P.; Jiang, Y.; Ren, Q. Roof Hydraulic Fracturing for Preventing Floor Water Inrush under Multi Aquifers and Mining Disturbance: A Case Study. Energies 2022, 15, 1187. https://doi.org/ $10.3390 /$ en15031187

Academic Editor: Dino Musmarra

Received: 6 January 2022

Accepted: 4 February 2022

Published: 6 February 2022

Publisher's Note: MDPI stays neutral with regard to jurisdictional claims in published maps and institutional affiliations.

Copyright: (C) 2022 by the authors. Licensee MDPI, Basel, Switzerland. This article is an open access article distributed under the terms and conditions of the Creative Commons Attribution (CC BY) license (https:// creativecommons.org/licenses/by/ $4.0 /)$.

\begin{abstract}
Water inrush disasters from the coal seam floor occur frequently due to the high water pressure of the Ordovician limestone aquifer, multiple aquifers and strong mining disturbance. We presented a model of water-resisting key strata (WRKS) to investigate the mechanism of floor water inrush from multiple aquifers in deep coal mines. Roof hydraulic fracturing (RHF) for controlling floor water inrush and multi-parameter monitoring were proposed and validated in the Xingdong coal mine in Xingtai, Hebei Province. The results indicated that the periodic weighting step of the test working face after RHF was $9.53 \mathrm{~m}$, which was $61.42 \%$ less than that of the working face without RHF $(24.7 \mathrm{~m})$. The floor failure depth was $30 \mathrm{~m}$, which was $34.4 \%$ less than that of the zones without RHF $(45.7 \mathrm{~m})$. Hydraulic fracturing weakened the strength of the overlying strata to control the weighting step and reduce the mining disturbance stress, and the stability of the floor WRKS was enhanced, thereby preventing water inrush from the coal seam floor. The research results provide a solution for preventing floor damage and floor water inrush under strong mining disturbance and in complex hydrogeological environments in deep mining.
\end{abstract}

Keywords: deep mining; high water pressure; mining disturbance; water inrush prevention; Xingdong coal mine

\section{Introduction}

Water inrush from the coal seam floor is a dynamic disaster in coal mines [1-3]. Mine water inrush has always been a critical technical problem limiting the safe production of water-rich mines [4-6]. Furthermore, underground drainage from coal mines has caused many ecological and environmental problems $[7,8]$. At present, most coal mines in the North China Carboniferous-Permian coalfield are transitioning to deep mining or exploring lower coal groups. Deep rock mass is located in an environment with high in situ stress and high water pressure [9], and the risk of floor water inrush is increased [10]. Therefore, it is of great significance to investigate the mechanism and prevention technology of floor water inrush in deep mining.

The techniques for floor water inrush prevention include drainage depressurization [11], grouting transformation of floors and aquifers [12,13] and reform of coal mining methods. Dewatering an aquifer refers to pumping out the aquifer to reduce water pressure. However, the aquifer at the bottom of the coal seam in deep mines in the North China coalfield is the Ordovician limestone aquifer. The Ordovician limestone aquifer is so thick and water-abundant [14] that it cannot be blocked by a grouting curtain for drainage and pressure reduction. Dewatering the aquifer also causes much water waste [5] and various ecological problems [15]. Floor grouting reinforcement is the most common method for preventing and controlling floor water $[12,16,17]$. Grouting techniques for controlling water 
inrush in coal mines can be divided into two categories: local floor grouting reinforcement and regional advanced governance [18].

Some deep mines have adopted floor reinforcement technology or regional advanced treatment technology. Although the risk of floor water inrush has been dramatically reduced, floor water burst still occurs after grouting treatment. For instance, after regional governance was introduced in the Wutong-Zhuang and Xingdong coal mines, floor water inrush still occurred during mining $[19,20]$. Floor grouting in the Chensilou coal mine aggravated the risk of floor water inrush at other working faces [21]. Other coal mines have also experienced floor water inrush after grouting, such as the Zhaogu No. 1, Guhanshan, Jiulishan and Yanmazhuang coal mines [22]. These results show that these control technologies are useful for preventing floor water inrush in shallow mining, but they cannot successfully eliminate floor water inrush in deep mining. Under high water pressure and strong mining disturbance in deep mining, controlling floor water inrush becomes more difficult $[10,23,24]$.

Floor water inrush disasters often occur during the period of first weighting, periodic weighting or "square weighting" (the advancing distance of the longwall face is almost equal to the length of the longwall face) [23-26]. The disturbance stress induced by coal seam mining is a key driving force evoking water inrush, so the changing coal mining method is a simple and effective prevention measure. Special coal mining methods, such as strip mining [27] and backfill mining [28] with low resource recovery rates, high cost and low production efficiency, have failed to realize high-yield and high-efficiency mining. Hydraulic fracturing is another commonly used measure for reducing excessive stresses [29]. Hydraulic fracturing is to enhance the collapsibility and fragility of the roof rock by pretreating rock mass to generate hydraulic fractures. Hydraulic fracturing has been applied to control the severe pressure of hard roofs [30,31] and control top coal caving in hard thick coal seams in coal mines [32]. However, there have only been a few case studies on the mechanism and effect for controlling floor water inrush by RHF in coal mining practice. According to the "down three zone" analysis method [33,34], the intact strata zone is the main stratum to prevent floor water inrush. According to the theory of WRKS, a certain thickness and high-strength hard rock strata in the protected zone beneath the coal seam floor is regarded as the key stratum [22,23,35-38]. The stability of the key stratum and its ability to resist the progressive rise of confined water determines whether water inrush can occur from the coal seam floor.

In this paper, a model that includes WRKS was established to investigate the mechanism and prevention methods of floor water inrush under complex hydrogeological conditions in deep mining. The mechanism and prevention proposed were verified in panel 2129 in the Xingdong coal mine, Hebei Province, China, where there are complex hydrogeological conditions with five aquifers. Mining-induced stress, deformation of the surrounding rock, floor microseismicity, Ordovician limestone aquifer water level, floor failure depth and floor water inrush risk before and after prevention were compared and analyzed via multi-parameter monitoring. Finally, the mechanism and effect of RHF in preventing floor water inrush were discussed. This study contributes to the understanding of the floor water inrush mechanism and comprehensive prevention technology in deep mining and provides a reference basis for comprehensive prevention and control technology of floor water inrush in deep mining under pressure.

\section{Study Area}

\subsection{Overview of the Mine and Panel 2129}

The Xingdong coal mine is in the northeast of the Hanxing coalfield in Hebei Province, China (Figure 1a,b). The mining length is $3.8 \mathrm{~km}$ and $3.4 \mathrm{~km}$ wide and covers an area of $14.5 \mathrm{~km}^{2}$. The mining depth is $1038.5-1271.5 \mathrm{~m}$. The coal seam is mined via the longwall mining method, and the roof is managed using the caving method. 


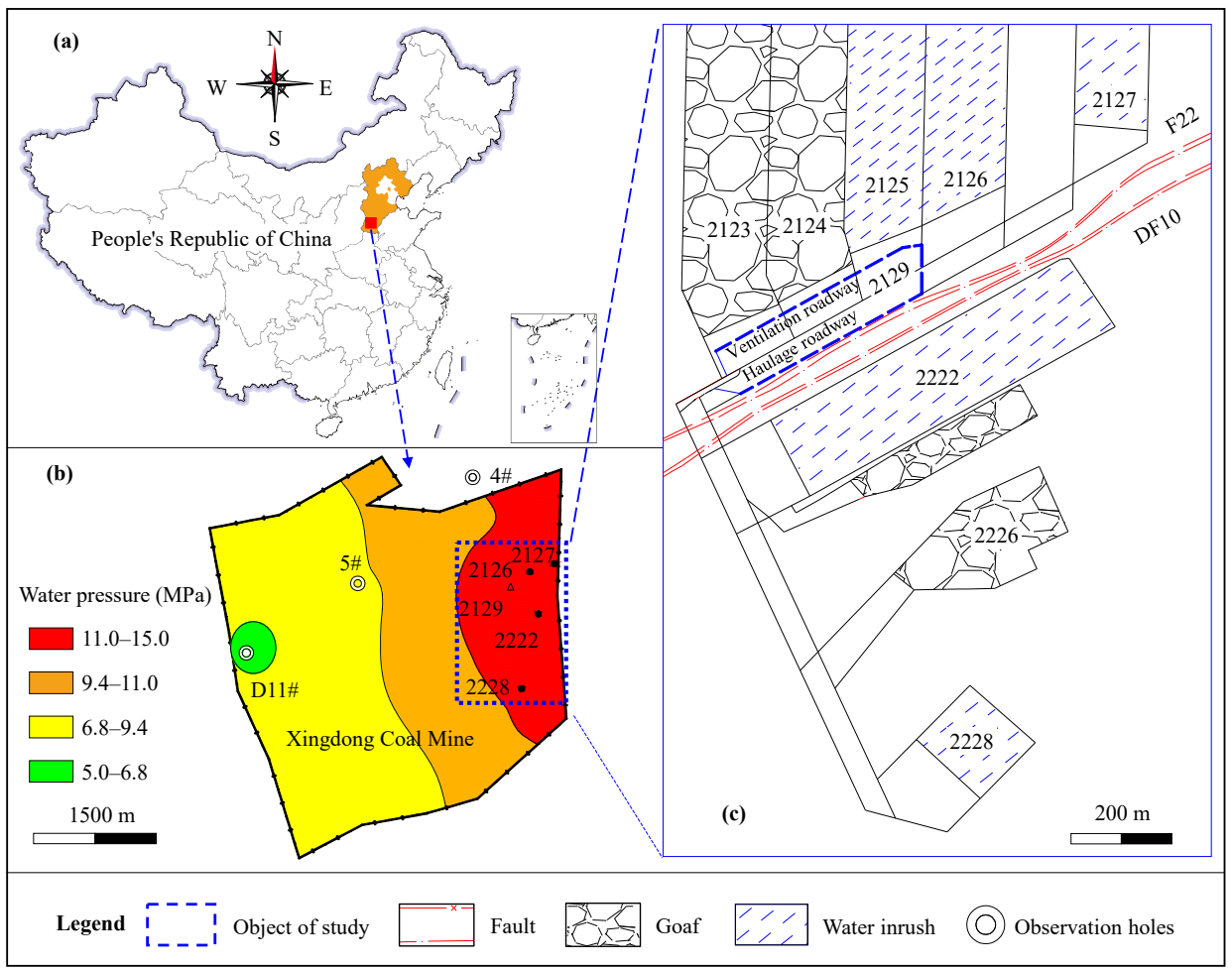

Figure 1. Location of the study area and layout of floor water inrush faces: (a) Location of the Xingdong coal mine; (b) Water pressure of Ordovician limestone aquifer; (c) Object of study and layout of floor water inrush faces.

The mining depth of panel 2129 in the Xingdong coal mine is 1027-1125 m and $92.5 \mathrm{~m}$ wide, and the lengths of the ventilation and haulage roadways are $416 \mathrm{~m}$ and $367 \mathrm{~m}$, respectively. The ventilation roadway is adjacent to the goaf of panels 2125, 2126 and 2127, which have floor water inrushes, and panels 2123 and 2124, which do not. The haulage roadway is adjacent to panel 2222 with floor water inrush and the F22 and DF10 normal faults. The drop of the faults is $9-58 \mathrm{~m}$ and $8-40 \mathrm{~m}$, respectively. The hydrogeological and mining conditions of panel 2129 are complex, with a high risk of floor water inrush. Figure 1c shows the mining layout of panel 2129.

\subsection{Geologic Characteristics}

The Xingdong coal mine extracts coal seam $2 \#$ with a dip angle of $5-15^{\circ}$ and a thickness range of $2.65-5.48 \mathrm{~m}$. The immediate roof of the coal seam 2\# is siltstone that is $3.60 \mathrm{~m}$ thick, and the main roof is fine sandstone with a thickness of $9.55 \mathrm{~m}$. The lithology of the floor strata is siltstone and sandy mudstone. Figure 2a shows the physical and mechanical parameters of coal and rock strata. There are five aquifers in the floor of coal seam 2\# (Figure 2b). The Ordovician limestone aquifer is a fractured karst aquifer with a total thickness of $545 \mathrm{~m}$ and water pressure of 11-15 MPa (Figure 1b) [31], which is referred to as a "thick aquifer" in this paper. Other aquifers with small thickness and low water content are referred to as "thin aquifers". The hydraulic pressure of Ordovician limestone under the NO.2129 longwall panel is $12.26 \mathrm{MPa}-12.96 \mathrm{MPa}$, while the hydraulic pressure of thin aquifers is small, taken as 0 in this paper. There are five aquifuges in the floor that are composed of sandstone, mudstone, sandy mudstone and coal. Geological exploration data show that the hydrogeological conditions in the Xingdong mine are complex, and faults and karst collapsed pillars are well developed in the mining area. 


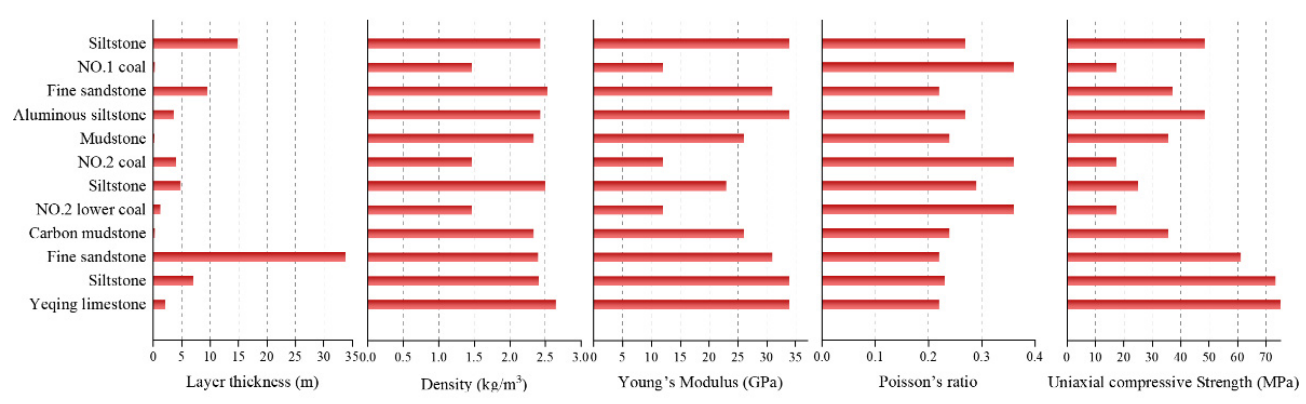

(a)

\begin{tabular}{|l|c|}
\hline \multicolumn{1}{|c|}{ Description } & $\begin{array}{c}\text { Thick- } \\
\text { ness(m) }\end{array}$ \\
\hline Siltstone, thick layer and dense & 14.96 \\
\hline NO.1 coal & 0.35 \\
\hline $\begin{array}{l}\text { Fine sandstone, thick layer and } \\
\text { dense }\end{array}$ & 9.55 \\
\hline $\begin{array}{l}\text { Aluminous siltstone } \\
\text { Mudstone with plant fossil } \\
\text { fragments }\end{array}$ & 3.6 \\
\hline $\begin{array}{l}\text { NO.2 coal } \\
\text { Siltstone, medium fine sandstone, } \\
\text { sandy mudstone and coal seam }\end{array}$ & 47.11 \\
\hline $\begin{array}{l}\text { Yeqing aquifer } \\
\text { Mudstone, sandy mudstone, } \\
\text { siltstone and coal seam }\end{array}$ & 0.2 \\
\hline $\begin{array}{l}\text { Fuqing aquifer } \\
\text { mudstone and coal seam }\end{array}$ & 2.18 \\
\hline $\begin{array}{l}\text { Siltstone, mudstone, medium fine } \\
\text { sandstone and coal seam }\end{array}$ & 41.6 \\
\hline $\begin{array}{l}\text { Baqing aquifer } \\
\text { sandstone aquifer }\end{array}$ & 15.68 \\
\hline \begin{tabular}{l} 
Ordovician limestone aquifer \\
\hline
\end{tabular}
\end{tabular}

(b)

Figure 2. Geological conditions: (a) mechanical parameter of the coal seam and roof and floor strata; (b) comprehensive columnar schematic diagram.

\subsection{Characteristics of Floor Water Inrush}

It was found that roadway deformation increased significantly when the floor water inrush occurred. Therefore, the control effect can be evaluated by monitoring roadway deformation. Water inrush accidents still occur through the coal seam floor after regional advanced treatment in the deep part of the mine above highly confined aquifers in the Xingdong coal mine (Figure 1c).

Support resistance was generally small before floor water inrush and then increased sharply when water inrush occurred. Some or all the hydraulic supports in the working face were crushed (Table 1). According to geological data and the characteristics of floor water inrush [32], under high in situ stress and high water pressure in deep mining, it is difficult for the roof strata to collapse, resulting in a large overhanging roof area and thereby generating strong mining disturbance. Strong mining disturbance is the main 
factor triggering floor water inrush above a confined aquifer and multi-aquifers in the deep part of the Xingdong coal mine. Furthermore, the hydrogeology and mining conditions of panel 2129 are more complex than those of panels with floor water inrush, presenting a higher risk of floor water inrush during mining.

Table 1. Statistics of water inrush faces.

\begin{tabular}{|c|c|c|c|c|c|}
\hline Water Inrush Faces & $\begin{array}{l}\text { Water Inrush } \\
\text { Location }\end{array}$ & $\begin{array}{c}\text { Percentage of } \\
\text { Crushed Supports } \\
(\%)\end{array}$ & $\begin{array}{c}\text { Periodic Weighting } \\
\text { Step (m) }\end{array}$ & $\begin{array}{l}\text { Regional Advanced } \\
\text { Treatment before } \\
\text { Mining (Yes/No) }\end{array}$ & $\begin{array}{c}\text { Maximum Water } \\
\text { Inflow } \\
\left(\mathrm{m}^{3} / \mathrm{h}\right)\end{array}$ \\
\hline 2125 & $\begin{array}{c}\text { Goaf near stop line } \\
\text { Goaf in the }\end{array}$ & No data & No data & Yes & 80 \\
\hline 2126 & $\begin{array}{l}\text { intersection of the } \\
\text { working face } \\
\text { and roadway }\end{array}$ & 89 & 18 & Yes & 278 \\
\hline 2127 & $\begin{array}{l}\text { Goaf in the } \\
\text { intersection of the } \\
\text { working face and } \\
\text { roadway } \\
\text { Goaf in the }\end{array}$ & 21 & 20 & No & 210 \\
\hline 2222 & $\begin{array}{c}\text { intersection of the } \\
\text { working face } \\
\text { and roadway }\end{array}$ & 30 & 24.7 & Yes & 285 \\
\hline 2228 & $\begin{array}{l}\text { Goaf in the } \\
\text { intersection of the } \\
\text { working face } \\
\text { and roadway }\end{array}$ & 100 & No data & Yes & 2649 \\
\hline
\end{tabular}

\section{Mechanism Analysis of Floor Water Inrush}

According to the geological conditions (Figure 2) and characteristics of floor water inrush in the Xingdong coal mine, the mode of water inrush from a multi-aquifer floor [39] driven by high confined water in Ordovician limestone and transferred by thin limestone aquifers is formed (Figure 3). Under the combined influence of high in situ stress, strong mining disturbance and high water pressure, the WRKS between the Ordovician limestone aquifer and Benxi limestone aquifer breaks first, and the highly confined water is conducted upward to the Benxi limestone aquifer. There is increased water pressure in the Benxi aquifer after conduction. When the water pressure is higher than the critical water pressure of WRKS, the WRKS is damaged. The confined water continues to rise into the upper thin limestone aquifer. The WRKS between the thin aquifers is destroyed layer by layer, and the Ordovician limestone aquifer is conducted upwards through the thin aquifers. When the highly confined water of Ordovician limestone is conducted upward to the Yeqing aquifer, Benxi, Daqing and Fuqing limestone aquifers are in the Ordovician limestone aquifer water-rising zone. The water-rising zone height of the Ordovician limestone aquifer $\left(h_{2}\right)$ is the distance from the Ordovician limestone to the uppermost WRKS (the WRKS between the Yeqing limestone and the coal seam).

When the critical water pressure that the uppermost WRKS can tolerate is less than the rising water pressure, the uppermost WRKS is broken. The confined water-rising zone (WRZ) connects with the water conductive failure zone (WCFZ), which may contribute to floor water inrush. Figure 3 a shows the water inrush mechanism from the floors of multiple aquifers, and Figure $3 b$ shows a schematic diagram of the Ordovician limestone aquifer connecting to the Yeqing aquifer. The WRZ is simplified, and the other thin aquifers are not drawn in Figure 3b. If the uppermost WRKS does not fracture, floor water inrush does not occur. Based on Figure 3b, the uppermost WRKS is selected to establish a mechanical model of the WRKS, as presented in Figure 3c. 


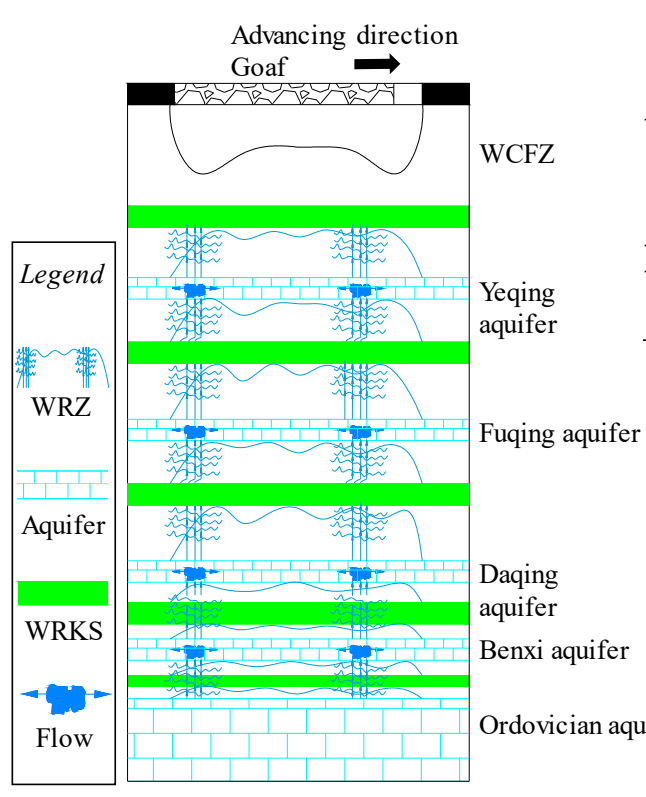

(a)

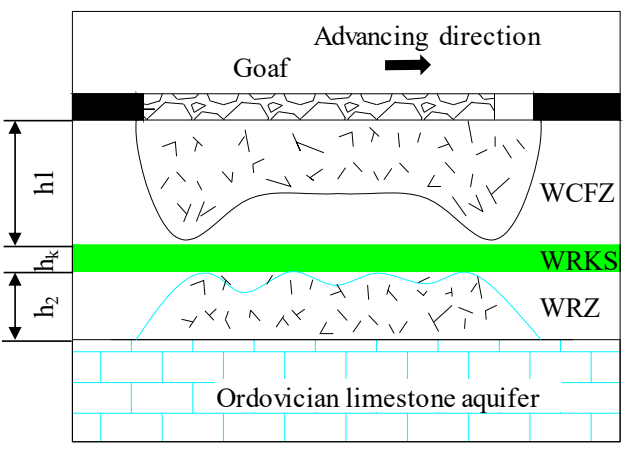

(b)

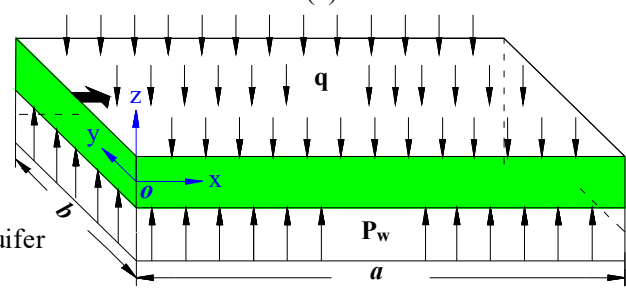

(c)

Figure 3. Schematic diagram of water inrush from multiple aquifers floor: (a) water inrush mechanism from multiple aquifers floor; (b) water in the Ordovician limestone aquifer rising to the Yeqing aquifer; (c) mechanical model of the water-resisting key strata in the floor.

The total vertical load on the upper surface of the WRKS is $q=q_{0}+\gamma_{1} h_{1}+\gamma_{\mathrm{k}} h_{\mathrm{k}}$, where $q_{0}$ is the caved goaf strata load, $\gamma_{1} h_{1}$ is the load of the rock above the WRKS and $\gamma_{\mathrm{k}} h_{\mathrm{k}}$ is the gravity of the WRKS. The main roof did not collapse before the initial weighting, and the floor strata of the goaf were only subjected to the load of the immediate roof, i.e., $q_{0}=\gamma_{0} h_{0}$. The overlying strata gradually broke during period weighting, and the load of the main roof rock strata transmitted progressively to the caved rock strata in the goaf. Therefore, the caved goaf strata load was the superposition of the load of the caved immediate roof and the gravity transmitted by the main roof rock strata, which can be equivalent to a uniform load of $q_{0}=k \gamma_{0} H$, and $0<k<1$, where $\gamma_{0}$ is the average bulk density of the roof, $h_{0}$ is the height of the caved zone ( 4 times the mining height (M) in this paper), $\gamma_{1}$ is the average bulk density of the floor rock above the WRKS, $h_{1}$ is the height of the floor rock above the WRKS, $\gamma_{\mathrm{k}}$ is the bulk density of the WRKS and $h_{\mathrm{k}}$ is the thickness of the WRKS.

According to the theory of elastic mechanics, the boundary conditions of a thin rectangular plate with four fixed edges [14,22,40] are satisfied in Equation (1):

$$
\left\{\begin{array}{l}
\omega_{x=0}=0,\left(\frac{\partial \omega}{\partial x}\right)_{x=0}=0 \\
\omega_{x=a}=0,\left(\frac{\partial \omega}{\partial x}\right)_{x=a}=0 \\
\omega_{y=0}=0,\left(\frac{\partial \omega}{\partial y}\right)_{y=0}=0 \\
\omega_{y=a}=0,\left(\frac{\partial \omega}{\partial y}\right)_{y=a}=0
\end{array}\right.
$$

According to the theory of elastic thin plates, the deflection expression of the WRKS that satisfies Equation (1) is selected, as shown in Equation (2):

$$
\omega(x, y)=\sum_{m=1}^{\infty} \sum_{n=1}^{\infty} \mathrm{A}_{m n} \sin ^{2}(m \pi x / a) \sin ^{2}(n \pi y / b)
$$

where $m$ and $n$ are positive integers and $\mathrm{A}_{m n}$ is the coefficient. 
The accuracy can meet the engineering requirements by substituting $m=n=1$, and then the deflection function can be obtained as Equation (3):

$$
\omega(x, y)=A \sin ^{2}\left(\frac{\pi x}{a}\right) \sin ^{2}\left(\frac{\pi y}{b}\right)
$$

In accordance with the principle of minimum potential energy in elastic mechanics, the coefficient of the deflection function can be calculated:

$$
\left\{\begin{array}{c}
\mathrm{A}=\frac{a^{4} b^{4}\left(P_{w}-q\right)}{D \pi^{4}\left(3 a^{4}+2 a^{2} b^{2}+3 b^{4}\right)} \\
D=E h_{\mathrm{k}}^{3} / 12\left(1-\mu^{2}\right)
\end{array}\right.
$$

where $D$ represents the bending stiffness of the WRKS, $E$ denotes the elastic modulus and $\mu$ is Poisson's ratio.

The stress component in the WRKS can be expressed by deflection by Equation (5):

The maximum (minimum) principal stress at any point in the WRKS model can be calculated by Equation (6):

$$
\begin{gathered}
\left\{\begin{array}{c}
\sigma_{x}=-\frac{E z}{1-\mu^{2}}\left(\frac{\partial^{2} \omega}{\partial x^{2}}+\mu \frac{\partial^{2} \omega}{\partial y^{2}}\right) \\
\sigma_{y}=-\frac{E z}{1-\mu^{2}}\left(\frac{\partial^{2} \omega}{\partial y^{2}}+\mu \frac{\partial^{2} \omega}{\partial x^{2}}\right) \\
\tau_{x y}=-\frac{E z}{1+\mu}\left(\frac{\partial^{2} \omega}{\partial x \partial y}\right)
\end{array}\right. \\
\sigma_{1}, \sigma_{3}=\frac{\sigma_{x}+\sigma_{y}}{2} \pm \sqrt{\left(\frac{\sigma_{x}-\sigma_{y}}{2}\right)^{2}+\tau_{x y}^{2}}
\end{gathered}
$$

Based on the Mohr-Coulomb criterion, Equation (7) is satisfied when shear failure occurs in the floor:

$$
\left\{\begin{array}{l}
\sigma_{\mathrm{c}}=\sigma_{1}-K \sigma_{3} \\
K=(1+\sin \varphi) /(1-\sin \varphi)
\end{array}\right.
$$

where $\varphi$ is the internal friction angle, $\sigma_{\mathrm{c}}$ is the uniaxial compressive strength of the WRKS, $K$ is the slope of the strength line and $K=(1+\sin \varphi) /(1-\sin \varphi)$.

We defined function $f(x, y)=\left(\sigma_{1}-K \sigma_{3}\right) / \sigma_{\mathrm{c}}$ as the water inrush criterion of the WRKS, and function $f(x, y)$ can be denoted as Equation (8):

$$
\begin{gathered}
f(x, y)=\frac{(1-K) A E z}{\sigma_{\mathrm{c}}(1-\mu)}\left[\frac{\pi^{2}}{a^{2}} \sin ^{2}\left(\frac{\pi y}{b}\right) \cos \left(\frac{2 \pi x}{a}\right)+\frac{\pi^{2}}{b^{2}} \sin ^{2}\left(\frac{\pi x}{a}\right) \cos \left(\frac{2 \pi y}{b}\right)\right] \\
+\frac{(1+K) E|A z|}{\sigma_{\mathrm{c}}(1+\mu)} \sqrt{\left[\frac{\pi^{2}}{a^{2}} \sin ^{2}\left(\frac{\pi y}{b}\right) \cos \left(\frac{2 \pi x}{a}\right)-\frac{\pi^{2}}{b^{2}} \sin ^{2}\left(\frac{\pi x}{a}\right) \cos \left(\frac{2 \pi y}{b}\right)\right]^{2}+\left[\frac{\pi^{2}}{a b} \sin \left(\frac{2 \pi x}{a}\right) \sin \left(\frac{2 \pi y}{a}\right)\right]^{2}}
\end{gathered}
$$

when $f(x, y)=1$, the point $(x, y)$ on the WRKS is in a critical failure state, and when $f(x, y)<1$, the WRKS remains stable, whereas water inrush occurs when $f(x, y)>1$.

When $f(x, y)=1$, we obtain the critical water pressure of WRKS can withstand as Equation (9):

$$
P_{c w}=q_{0}+\gamma_{1} h_{1}+\gamma_{\mathrm{k}} h_{\mathrm{k}}+\frac{\pi^{2} \sigma_{\mathrm{c}} h_{\mathrm{k}}^{2}\left(3 a^{4}+2 a^{2} b^{2}+3 b^{4}\right)}{12(K-\mu) a^{2} b^{4}}
$$

According to in situ monitoring data, the water pressure of the Yeqing aquifer is 0 $\mathrm{MPa}$, and the height of the original WRZ zone of the Yeqing aquifer is $0 \mathrm{~m}$. The water pressure of the uplifted Yeqing limestone aquifer is obtained:

$$
P_{y w}=P_{0}-\eta h_{2}
$$

where $P_{y w}$ is the water pressure of the uplifted Yeqing limestone aquifer, $P_{0}$ is the water pressure of the Ordovician limestone aquifer, $h_{2}$ is the distance from Ordovician limestone to the uppermost WRKS and $\eta$ is the pressure loss coefficient of confined water; the average value of each layer is $0.08 \mathrm{MPa} / \mathrm{m}$ from an in situ experiment. 
A critical state of floor water inrush occurs when $P_{c w}=P_{y w}$. Therefore, the critical water pressure of the Ordovician aquifer that the uppermost WRKS can withstand can be obtained:

$$
P_{c 0}=q_{0}+\gamma_{1} h_{1}+\gamma_{\mathrm{k}} h_{\mathrm{k}}+\frac{\pi^{2} \sigma_{\mathrm{c}} h_{\mathrm{k}}^{2}\left(3 a^{4}+2 a^{2} b^{2}+3 b^{4}\right)}{12(K-\mu) a^{2} b^{4}}+\eta h_{2}-P_{f w}
$$

where $P_{c 0}$ is critical water pressure of the Ordovician aquifer.

According to the characteristics of the Xingdong coal mine, the mining failure depth of panel 2222 adjacent to panel 2129 is $40 \mathrm{~m}$, then, $h_{1}=40 \mathrm{~m}$. According to the mining and geological parameters of panel 2129, the water pressure of Yeqing aquifer is $0 \mathrm{MPa}$, and the height of the original WRZ zone of Yeqing aquifer is $0 \mathrm{~m}$, then $h_{2}=129.01 \mathrm{~m}$ and $h_{\mathrm{k}}=47.11-h_{1}=7.11 \mathrm{~m}$. $\gamma_{0}$ is the average bulk density of roof rocks of coal seam $2 \#$ in Figure 2a. $\gamma_{1}$ is the bulk density of siltstone below the coal seam in Figure 2a. $\gamma_{k}, E, \varphi, \mu$ and $\sigma_{\mathrm{c}}$ are the average the bulk density, Young's modulus, internal friction angle, Poisson's ratio of siltstone and uniaxial compressive strength of siltstone and Fine sandstone above the Yeqing limestone in Figure 2a, respectively. $\eta$ is the pressure loss coefficient of confined water from an in situ experiment. These calculated parameter values are listed in Table 2. Substituting these parameters into Equation (11), the relationship between the caved goaf strata load, the stress recovery coefficient of the goaf, the height of the caved zone and the critical water pressure of the WRKS is shown in Figure 4. The critical water pressure of the WRKS increases linearly with the increase in the height of the caved zone or the stress recovery coefficient of the goaf, indicating that the deformation and fractures in the floor strata are compressed and closed by the caved roof strata, and the stability of the WRKS is improved, thereby reducing the risk of floor water inrush. Therefore, to ensure a safe mining of panel 2129, the caved goaf strata load (stress recovery coefficient) of the goaf floor can be increased by reasonable control of the height of the caved zone or by goaf backfilling.

Table 2. Parameter values of panel 2129 (data from Figure 2a and an in situ experiment).

\begin{tabular}{|c|c|c|c|c|c|c|c|c|c|}
\hline $\begin{array}{c}M \\
(\mathrm{~m})\end{array}$ & $\begin{array}{c}b \\
(\mathrm{~m})\end{array}$ & $\begin{array}{c}\gamma_{0} \\
\left(\mathrm{kN} / \mathrm{m}^{3}\right)\end{array}$ & $\begin{array}{c}\gamma_{1} \\
\left(\mathrm{kN} / \mathrm{m}^{3}\right)\end{array}$ & $\begin{array}{c}\gamma_{k} \\
\left(k N / m^{3}\right)\end{array}$ & $\begin{array}{c}E \\
(\mathrm{MPa})\end{array}$ & $\begin{array}{c}\sigma_{\mathrm{c}} \\
(\mathrm{MPa})\end{array}$ & $\begin{array}{c}\eta \\
(\mathrm{MPa} / \mathrm{m})\end{array}$ & $\mu$ & $\begin{array}{c}\varphi \\
\left(^{\circ}\right)\end{array}$ \\
\hline 3.95 & 93 & 22.4 & 25.0 & 24.1 & 32.5 & 67.2 & 0.08 & 0.23 & 41 \\
\hline
\end{tabular}

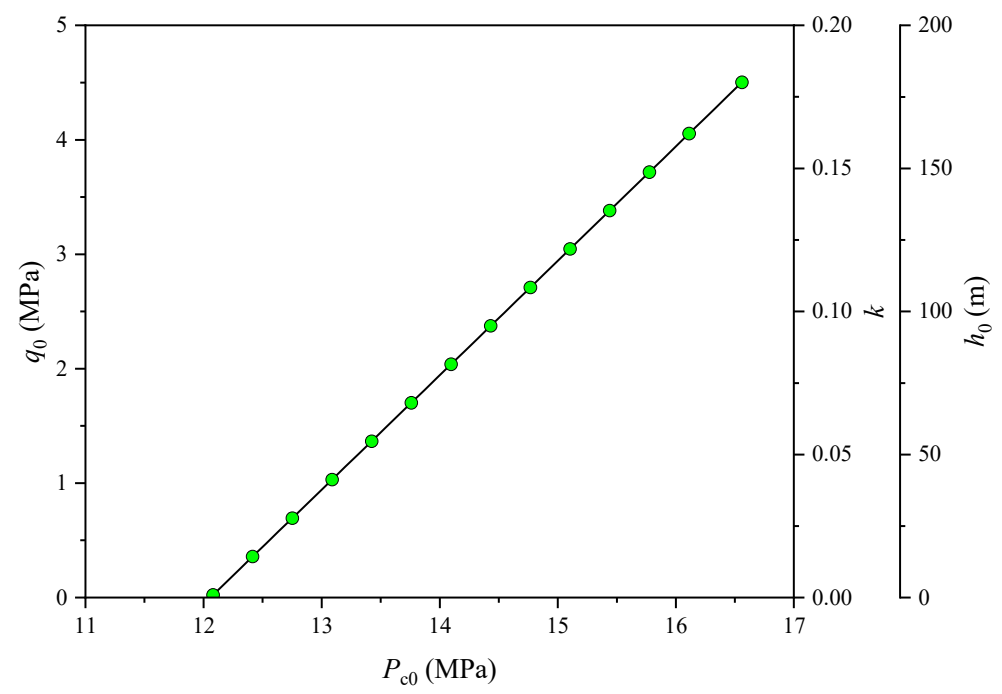

Figure 4. Relationship between critical water pressure $\left(P_{c 0}\right)$ and the caved goaf overburden load $\left(q_{0}\right)$, stress recovery coefficient $(k)$ and height of the caved zone $\left(h_{0}\right)(\mathrm{a}=93 \mathrm{~m})$. 
According to the width of panel 2129 and panels with water inrush, the critical water pressure of WRKS with advancing distance is shown in Figure 5. The critical water pressure that the WRKS can resist decreases rapidly with increasing length of the unloading zone for different panels; then, it reaches a minimum value when the length of the unloading zone equals its width; finally, the critical water pressure gradually increases. These results show that when the main roof strata are hard or it is difficult for them to collapse, the overhanging length of the main roof is large, resulting in the weighting step and the length of the unloading zone in the goaf becoming large, and the WRKS is more likely to fracture to cause floor water inrush. Therefore, reasonable control of the weighting step can prevent floor water inrush.

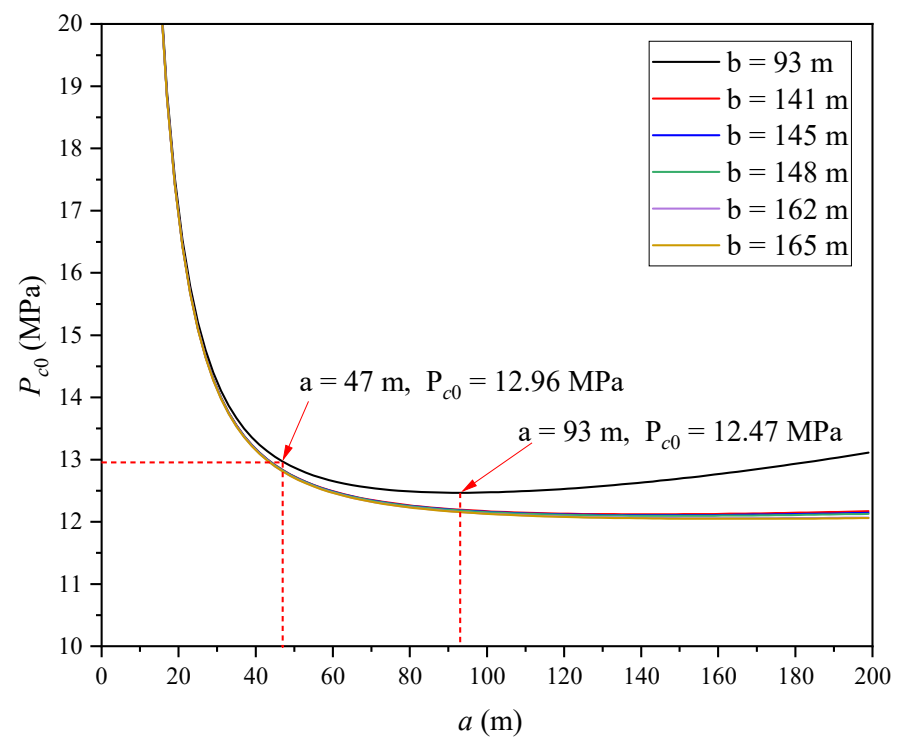

Figure 5. Relationship between critical water pressure $\left(P_{c 0}\right)$ and length of the unloading zone $(a)$ (when $h_{0}=15.8 \mathrm{~m}$, the parameters are shown in Table 2).

Figure 5 shows that critical water pressure reaches $12.96 \mathrm{MPa}$ when the length of the unloading zone of panel 2129 is $47 \mathrm{~m}$. To ensure the safe mining of panel 2129, the length of the unloading zone is restricted to $47 \mathrm{~m}$, with the initial weighting step being less than $47 \mathrm{~m}$. If the floor stress can be recovered after 2 or 4 periodic weighting steps, the periodic weighting step is less than $23.5 \mathrm{~m}$ or $11.75 \mathrm{~m}$. When the length of the unloading zone of panel 2129 is $93 \mathrm{~m}$, which is equal to its width, the critical water pressure reaches the minimum value of $12.47 \mathrm{MPa}$. Furthermore, measures to prevent floor water inrush and monitoring methods should be strengthened at these locations.

\section{Prevention Methods and Effect Evaluation of Floor Water Inrush}

\subsection{Roof Hydraulic Fracturing}

Based on the mentioned theoretical analysis, RHF was used to reduce mining disturbance and prevent floor water inrush. According to the test results of underground fracturing in other mining areas and panel 2129, the spacing of hydraulic fracturing boreholes was $20 \mathrm{~m}$. The RHF scheme and its parameters are illustrated in Figure 6. Fifteen boreholes were arranged on the roof of the mining side and coal pillar side. The hydraulic fracturing pressure was $60 \mathrm{MPa}$, and the continuous water injection time was more than $30 \mathrm{~min}$. 


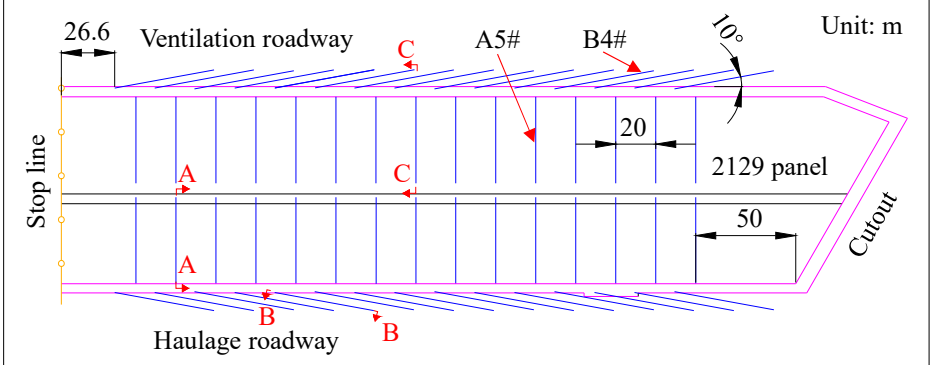

(a)

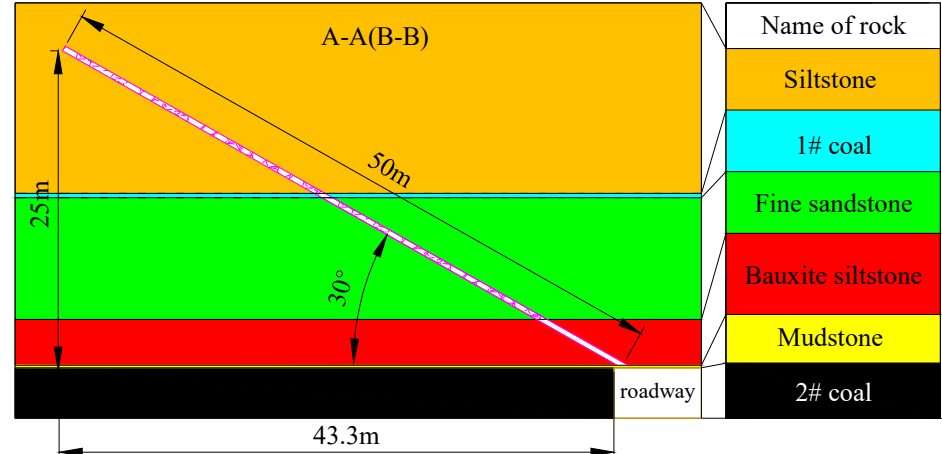

(b)

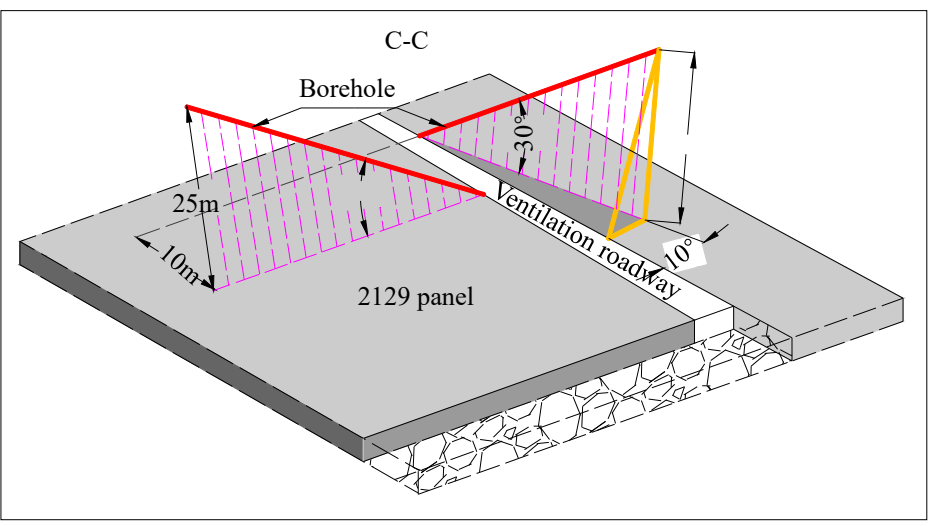

(c)

Figure 6. Layout of hydraulic fracturing boreholes: (a) layout of hydraulic fracturing boreholes; (b) section $\mathrm{A}-\mathrm{A}$ and section $\mathrm{B}-\mathrm{B}$; (c) three-dimensional diagram of section $\mathrm{C}-\mathrm{C}$.

\subsection{Multi-Parameter Effect Evaluation}

Multi-parameter field tests were conducted to evaluate the controlling effect of RHF. These investigations included borehole observations, mining face support stress, roadway roof-to-floor convergences, water level monitoring and microseismic monitoring. The layout of these monitoring stations is shown in Figure 7.

The development of fractures in boreholes before and after hydraulic fracturing was observed by borehole sighting instruments, and 10 boreholes were observed. The hydraulic support resistance was monitored to analyze roof weighting, and eight hydraulic support pressure gauges were evenly installed. Four monitoring stations were designed to monitor the convergence of the roof to floor and the convergence between the two sidewalls. The monitoring stations were numbered $\mathrm{C} 1, \mathrm{C} 2, \mathrm{C} 3$ and $\mathrm{C} 4$. Stations $\mathrm{C} 1$ and $\mathrm{C} 2$ were located $100 \mathrm{~m}$ away from the adjusted working face. The distance between stations C2 and C3 and $\mathrm{C} 1$ and $\mathrm{C} 4$ was $100 \mathrm{~m}$. Fifteen floor microseismic monitoring stations were installed, with an interval of 70-110 m, as shown in Figure 7. 


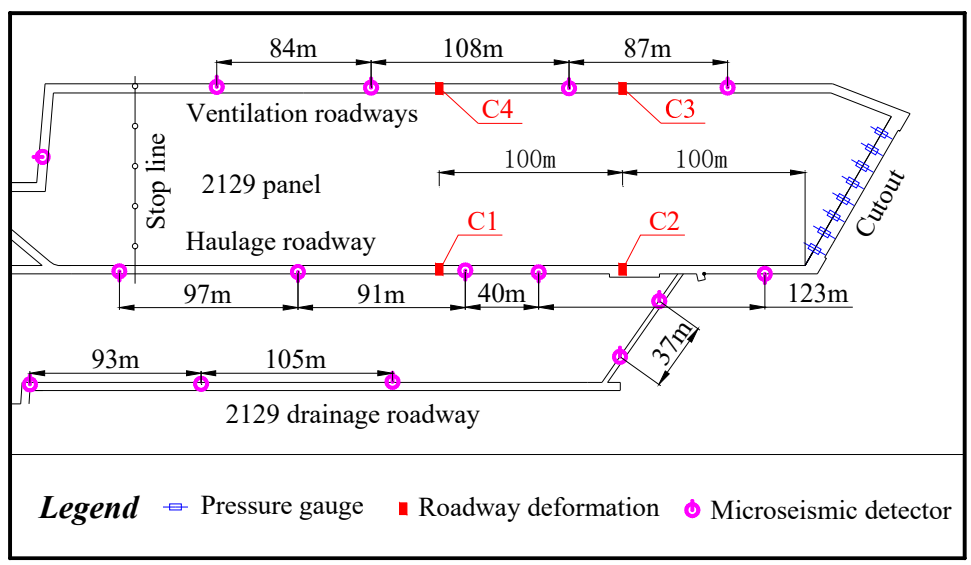

Figure 7. Layout of the monitoring stations.

\section{Results and Discussion}

\subsection{Effective Verification of RHF}

\subsubsection{Hydraulic Fracturing Fractures}

Hydraulic fracturing fractures can directly demonstrate the success of fracturing and the appropriateness of fracturing parameter designs [41]. Figure 8 shows many fractures developed in the boreholes after hydraulic fracturing. Fractures were not observed along boreholes A5\# and B4\# (Figure 6a), which did not undergo hydraulic fracturing, and the rock was intact at the planned hydraulic fracturing location (Figure 8a). At the same time, a large amount of water was ejected from the adjacent borehole during fracturing, indicating that the extension radius of hydraulic fracture reached $20 \mathrm{~m}$ or more. Unfortunately, we did not take photographs. Image clarity was reduced by the fact that the borehole was filled with gas, water and fractured rock. However, vertical fractures (along the axial direction of the hole) were generated in boreholes A5\# and B4\# (Figure 8b), demonstrating that the hard rock in the roof was successfully fractured [42]. Therefore, the cantilever roof can break through these hydraulic fractures and collapse into the goaf in time as the working face advances.

\subsubsection{Mining Face Support Stress}

Hydraulic fracturing is applied to make the roof strata more prone to caving, thereby reducing the roof weighting step and the dynamic load coefficient [43]. The resistance of hydraulic supports monitored in real time after RHF in panel 2129 was statistically analyzed and is shown in Figure 9. Field measurements showed that the average periodic weighting step was $4.97-13.83 \mathrm{~m}$, with an average of $9.53 \mathrm{~m}$, while the periodic weighting step of panel 2222 adjacent to panel 2129 was $24.7 \mathrm{~m}$. Thus, the periodic weighting step after the roof fractured decreased by $61.42 \%$. The dynamic load coefficient of periodic weighting was 1.23-1.47, with an average of 1.31. The field observations implied that the roof strata could collapse in a short time after coal mining, and the resistance of the supports against the roof stratum decreased. Support crushing and water inrush did not occur during periodic weighting. These results indicated that the weighting step and dynamic load coefficient of panel 2129 decreased after RHF. Moreover, the floor strata in the goaf were compacted in time, decreasing the impact of the roof overhang area. 


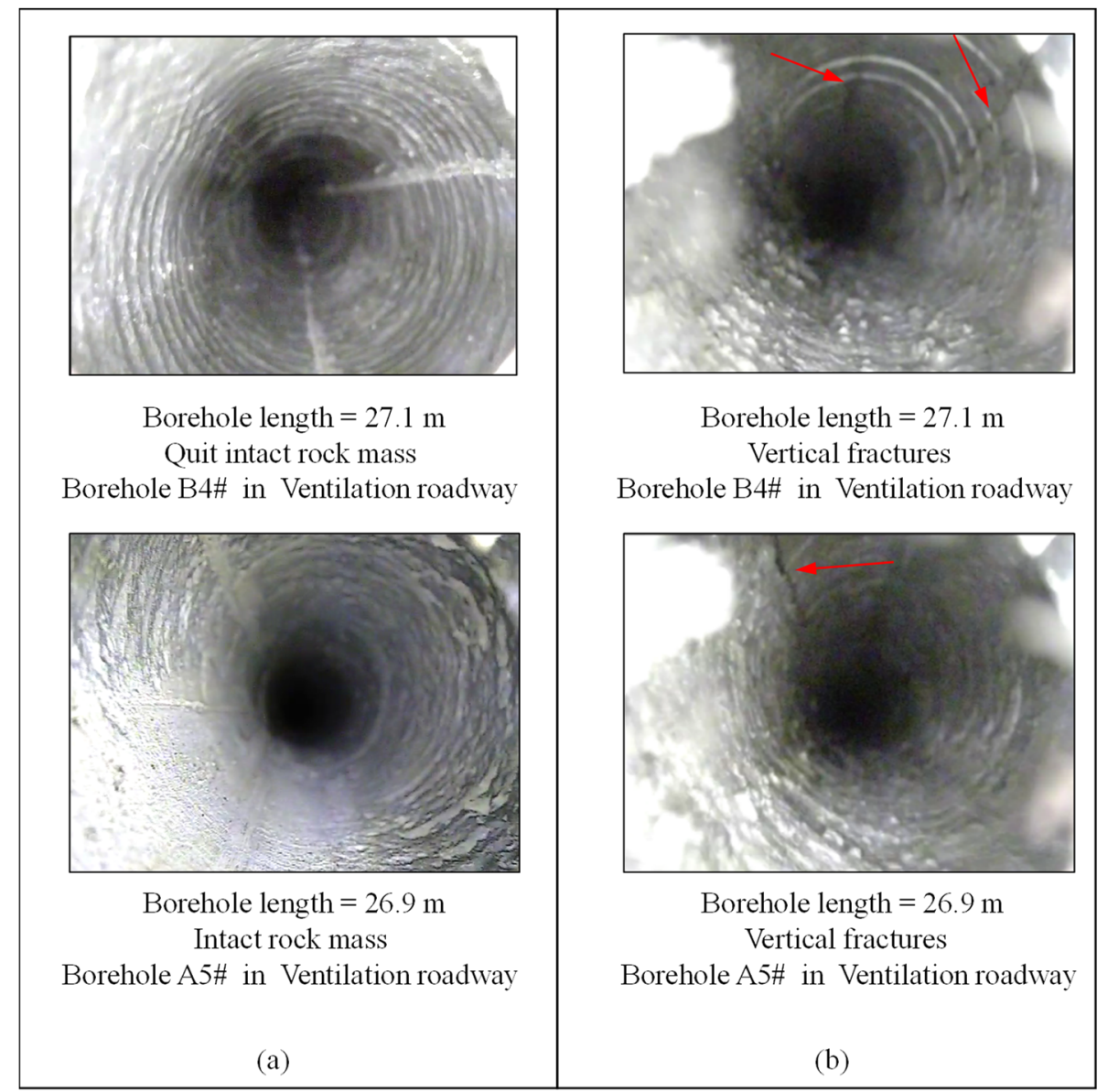

Figure 8. Comparison of fracture development before and after hydraulic fracturing: (a) before hydraulic fracturing; (b) after hydraulic fracturing.

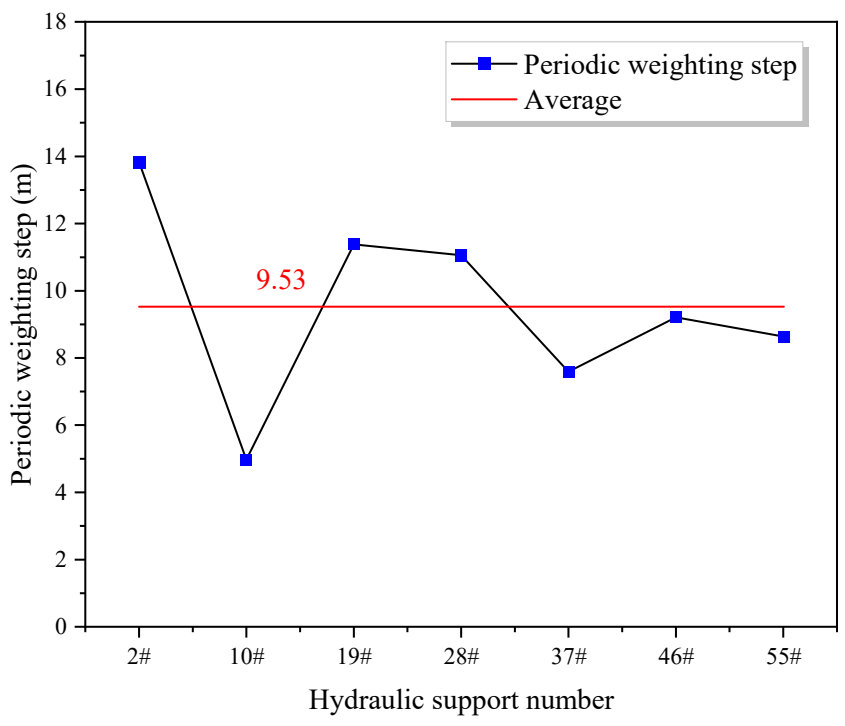

(a)

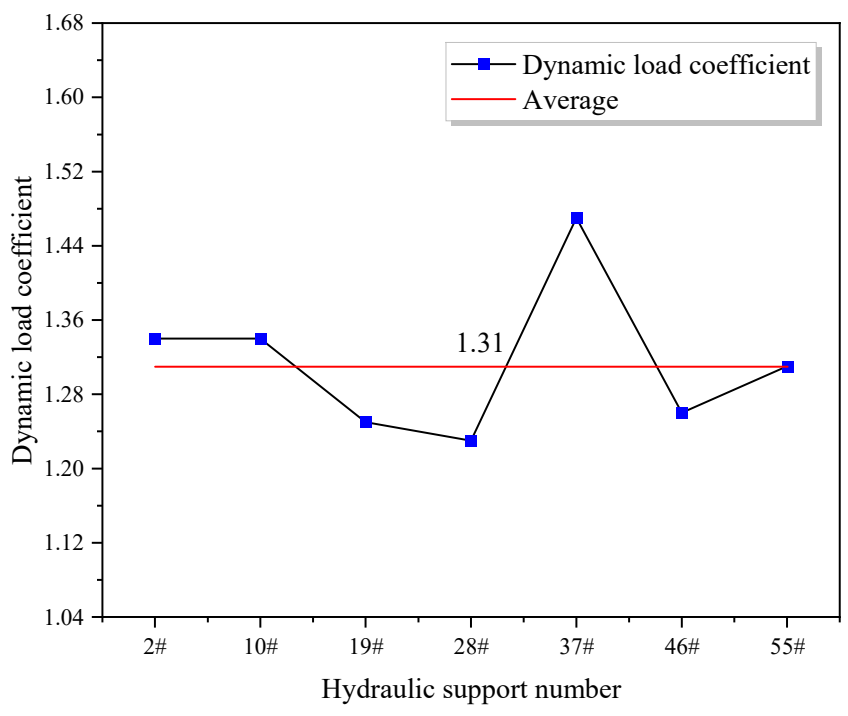

(b)

Figure 9. Characteristics of periodic weighting after hydraulic fracturing: (a) periodic weighting step; (b) dynamic load coefficient. 


\subsubsection{Roof-to-Floor Convergence}

It was found that roadway deformation increased significantly when floor water inrush occurred. Therefore, the control effect can be evaluated by monitoring roadway deformation. Two key indicators of roof-to-floor Convergence, namely, convergence magnitude and rate, were investigated during panel extraction. The convergence rate is denoted as the daily magnitude $(\mathrm{mm} / \mathrm{d})$ [44]. To quantify these key indicators, data from the four monitoring stations in the ventilation roadway and haulage roadway were analyzed (Figure 10). The data of stations $\mathrm{C} 1$ and $\mathrm{C} 2$ are the haulage roadway, and the data of stations $\mathrm{C} 3$ and $\mathrm{C} 4$ are the data of the return ventilation roadway in Figure 10. The deformation characteristics in the haulage roadway and ventilation roadway after RHF were consistent. The maximum rate of deformation of the roof-to-floor convergence was $66.7 \mathrm{~mm} / \mathrm{d}$ and $75 \mathrm{~mm} / \mathrm{d}$ in the haulage roadway and ventilation roadway after RHF, which was only $6.67 \%$ and $7.5 \%$ of that of panel $2228(1000 \mathrm{~mm} / \mathrm{d})$, respectively. A simple repair of the roadway could be sufficient to maintain production. These results suggests that the force suffered by the surrounding rock with RHF was smaller than that without RHF. Efficient release of mining stress by RHF achieved the desired effect.

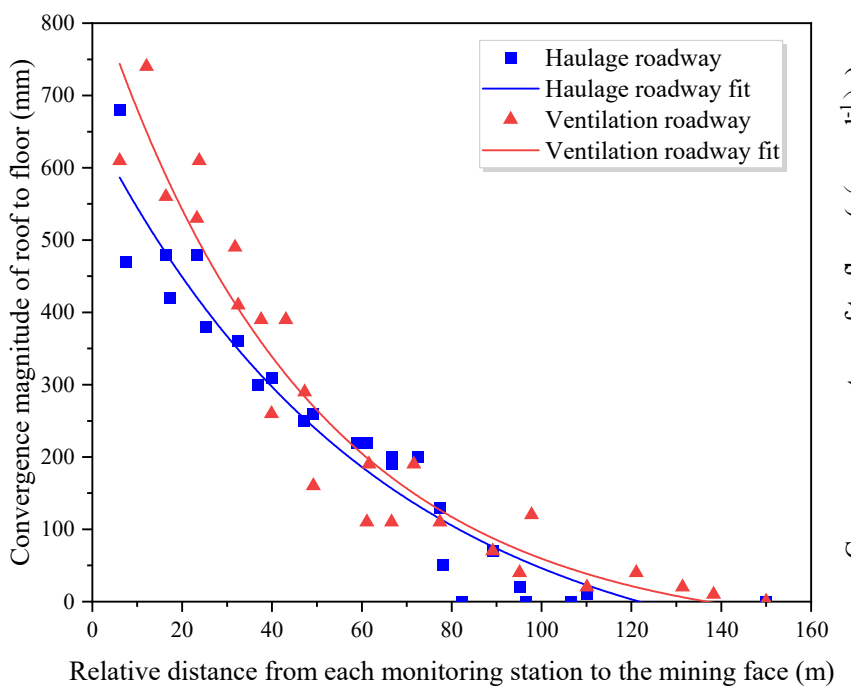

(a)

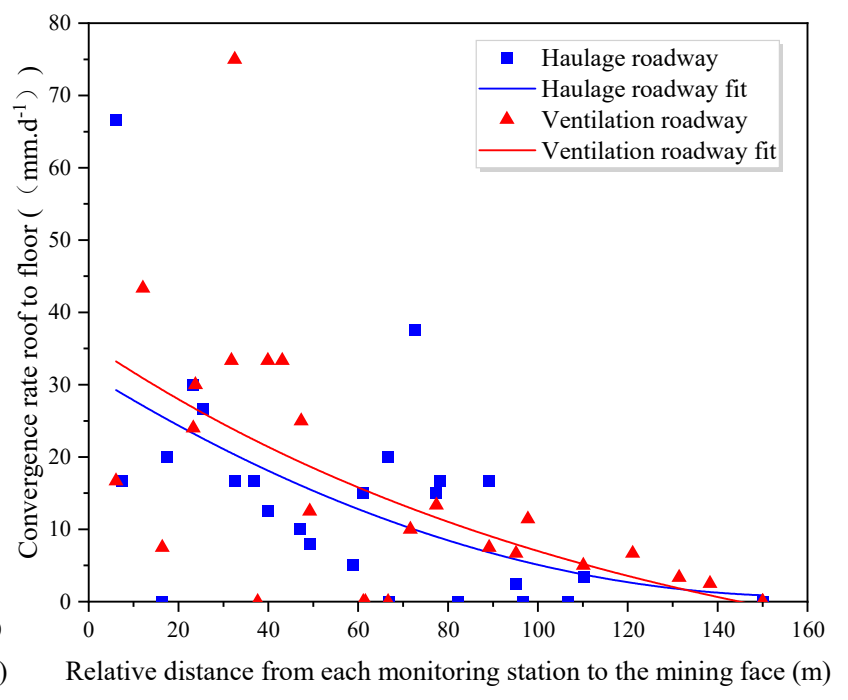

(b)

Figure 10. Deformation of the rocks surrounding the roadway rock: (a) convergence magnitude; (b) convergence rate.

\subsubsection{Water Level}

Field monitoring results revealed that the water level of the Ordovician limestone in the hydrological borehole varies widely before floor water inrush. Hence, the Ordovician limestone water level variation can be used as an early warning indicator of a floor water inrush [45]. On-site observation found that the water level variation of hydrologic observation holes 4\#, 5\# and D11\# was significant when the longwall panels near the NO.2129 panel occurred water inrush; thus, these hydrological holes were selected for analysis. The location of these hydrological holes is shown in Figure 1b. The water level variation in hydrologic observation holes 4\#, 5\# and D11\# near panel 2129 is shown in Figure 11. The water level in the hydrological observation borehole fluctuated less as the working face advanced. The changes in magnitude, rate and acceleration were used to study the characteristics of water level variation. Two anomalous stages of water level variation were located at the working face advancing distances of 45.4-47.6 m (I) and 80-85 m (II). Anomalous stage I was in the first weighting period, while stage II was in the "square weighting period" ("square" means that the distance that the working face advanced equals to the working face width). These results indicated that the higher the intensity of the mining activity, the larger the water level changes that occurred. The Ordovician limestone water would still 
rise during roof weighting after RHF, resulting in water level fluctuation. However, the water level of the Ordovician limestone fluctuates slightly after the implementation of RHF (Figure 11), and water flow from the floor around the working face was not found when the water level fluctuated abnormally.
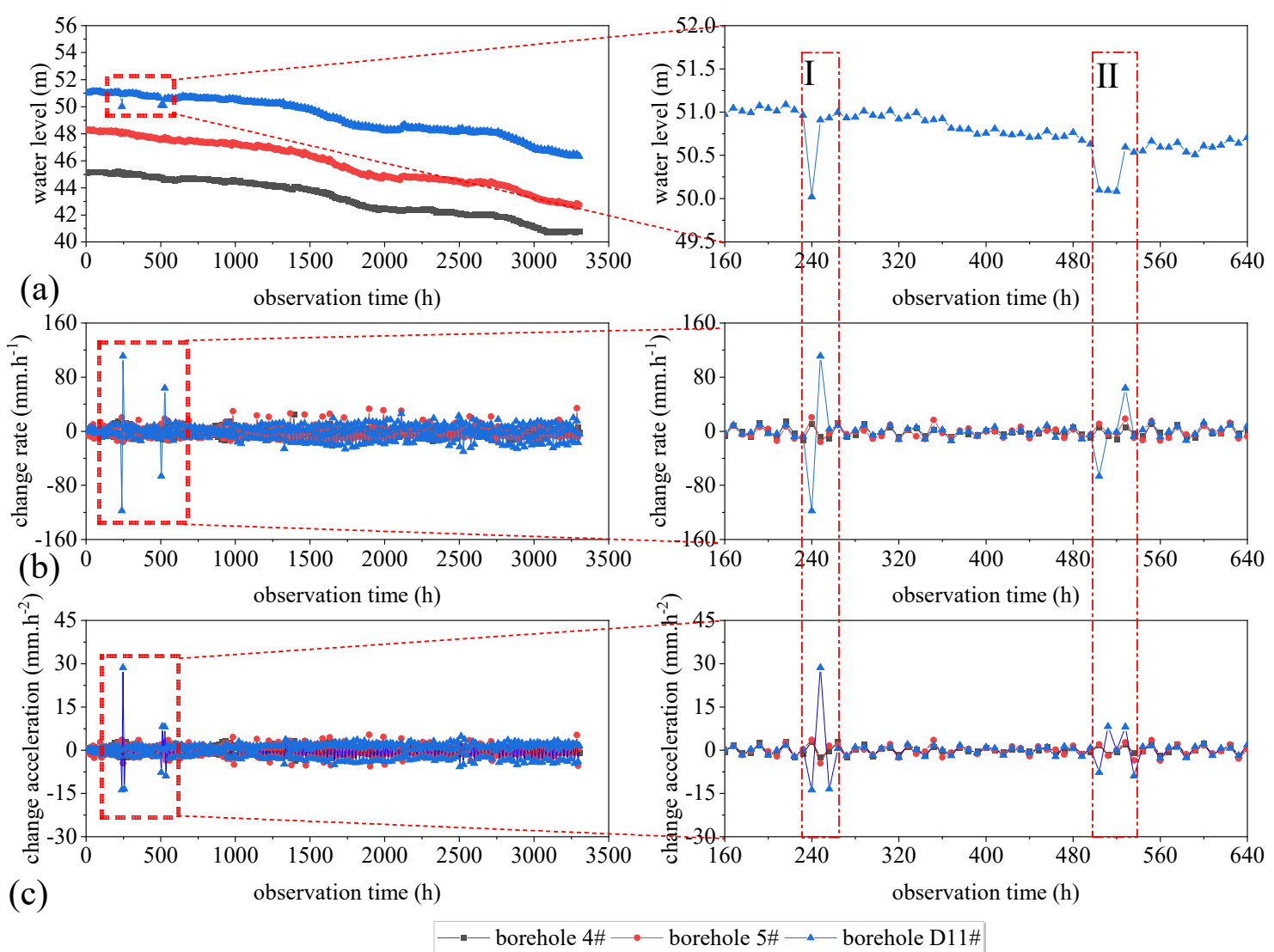

(c)

observation time (h)

—— borehole $4 \#$ —— borehole $5 \#$ —— borehole D11\#

Figure 11. Water level variation in hydrologic holes near the 2129 working face: (a) water level; (b) change in the water level rate; (c) change in the water level acceleration.

\subsubsection{Water Conducting Channel Evolution}

The formation process of the water conducting channels and the damage degree of the surrounding rock can be determined using microseismic events [4,46-49]. The microseismic monitoring system in the Xingdong coal mine recorded signals from 10 January 2019 to 6 May 2019. During this period, panel 2129 was first adjusted and then advanced normally. Figure 12a shows the progress of the working face and the spatial distribution of microseismic events in the floor in the advancing direction. Figure $12 \mathrm{~b}$ shows the distribution of microseismic events at different floor depths. Approximately $86 \%$ of the microseismic events occurred at a depth of $0-47.11 \mathrm{~m}$, indicating that the fracture location of the floor was mainly concentrated $47.11 \mathrm{~m}$ below the coal seam.

The precise spatiotemporal distribution of microseismic events is analyzed in detail via three views, viz., the top view, view $1\left(\mathrm{~A}-\mathrm{A}^{\prime}\right)$ and view 2(B-B') (Figure 12c). In the top view (Figure 12c), microseismic events clustered in the floor rock mass below the working face. Then, a large number of events accumulated around the abandoned roadways, isolated coal pillars and faults, but the event density of the fault-affected zone was significantly greater than that of the other places. View 1 shows that microseismic events developed in all layers of the floor with a tendency to interconnect but without developing a water flow channel (Figure 12c). View 2 shows that microseismic events were concentrated in the floor rocks underneath the working face. According to views 1 and 2 (Figure 12c), the majority of microseismic events developed $30 \mathrm{~m}$ below the floor (Figure 12c), and the 
farther the distance from the coal seam, the fewer seismic events there were. During the mining process, the water inrush channel was not detected onsite. Many microseismic events were detected in the upper part of the fault. However, few microseismic events occurred in the lower part of the fault. Therefore, a concentrated zone of microseismic events did not develop from the lower end to the upper end of the fault, indicating that the fault was not activated.

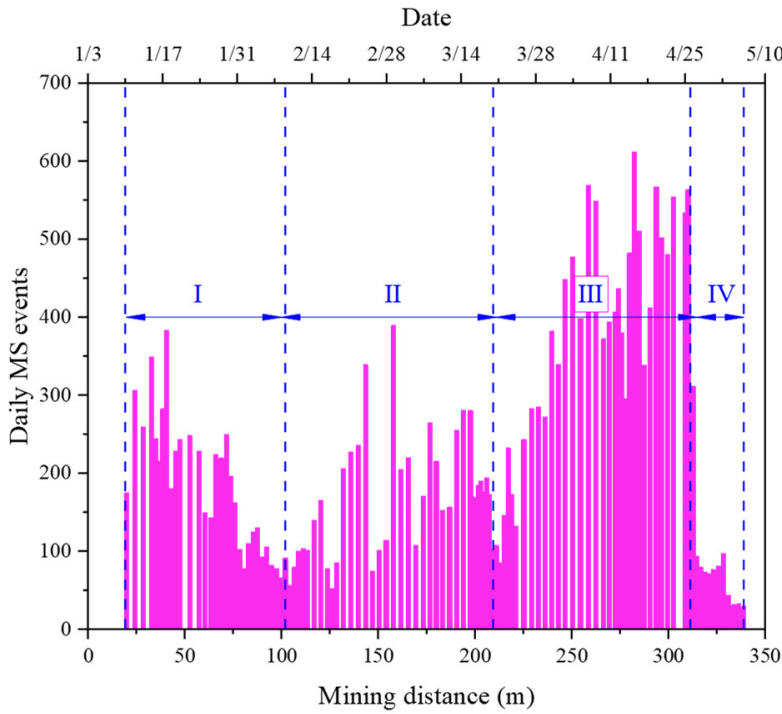

(a)

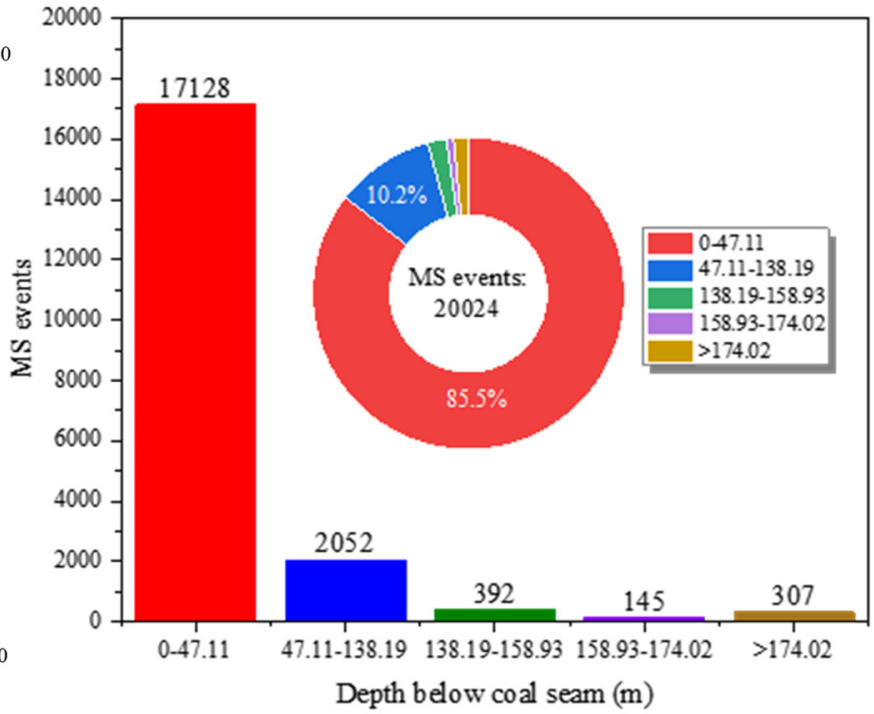

(b)
The top view
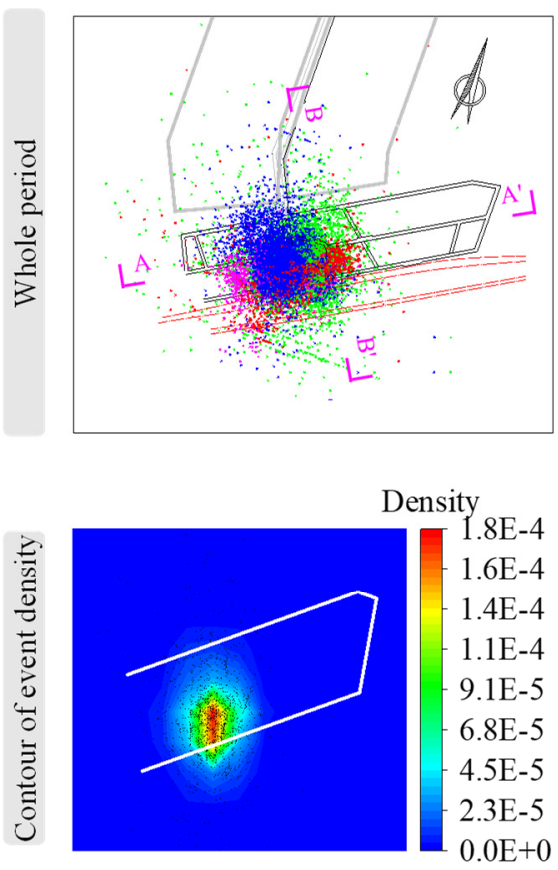

View 1
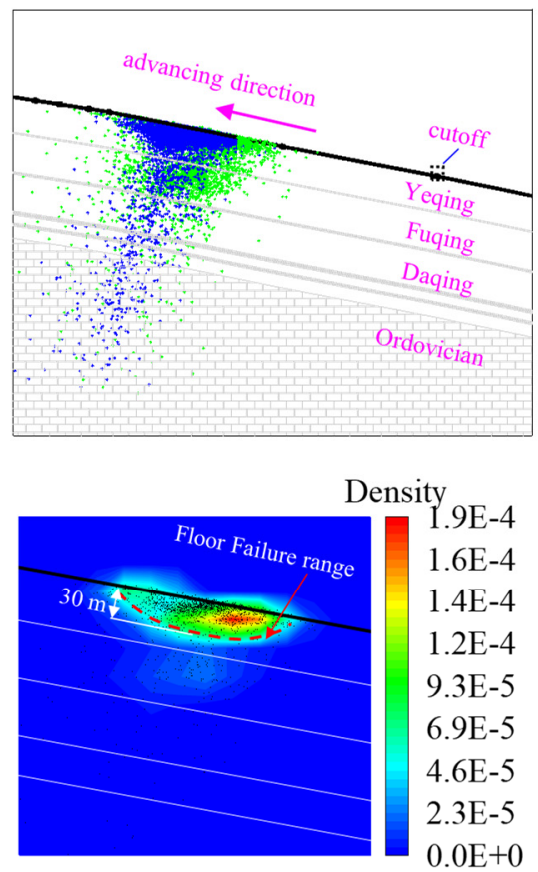

View 2
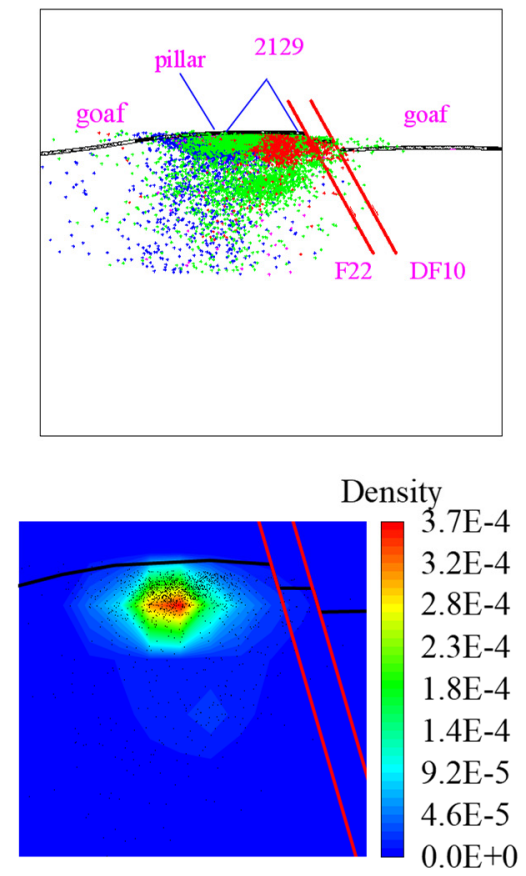

(c)

Figure 12. Distribution of MS events in the floor: (a) distribution of MS events along strike; (b) distribution of MS events in the floor along the floor depth; (c) distribution of MS events during monitoring. 
To gain insight into the development of the floor water inrush channel as the working face advanced, the microseismic monitoring period was divided into four parts depending on the microseismic distribution characteristics as shown in Figure 13. During period I, the maximum number of microseismic events was 383 due to initial weighting when the working face advanced to $40.85 \mathrm{~m}$. Microseismic events gradually gathered, and it was possible to develop leakage channels. The microseismic events gathered on the upper part of the fault plane, indicating that the rock cracks near the upper part of the fault plane began to activate. During period II, the maximum number of microseismic events was 389 when the working face reached $158 \mathrm{~m}$. Some microseismic events appeared at the top of the Ordovician limestone aquifer, indicating that the disturbance intensity caused by mining was enhanced, and the microfissure cluster extended gradually to the deep rock strata. The rock mass on the upper part of the fault plane continued to activate and extended gradually downward to the fault plane. During period III, the maximum number of microseismic events was 612 due to periodic weighting when the working face advanced to $282.6 \mathrm{~m}$. Although there were many microseismic events in this stage, the microfractures were widely distributed, without forming a water-conducting channel, and no water inrush occurred on site. The density of microseismic events on the upper part of the fault plane gradually decreased, indicating that the activation ranges of the fault plane did not continue to develop toward the lower rock mass. During period IV, the maximum number of microseismic events was 97 when the working face advanced to $328.6 \mathrm{~m}$. During this stage, the microseismic events decreased rapidly, and the microcracks were mainly concentrated within $20 \mathrm{~m}$ below the coal seam floor. The microseismic events on the fault plane also decreased suddenly, indicating that the amount of fault slip was quite small during this stage.

According to the distribution of microseismic events, the floor failure range was obtained as shown in Figure 12c, and the floor failure depth was calculated to be $30 \mathrm{~m}$ after RHF [46,47]. The fracture extension area formed by mining did not penetrate the WRKS or unconnected WRZ. Moreover, the fault did not activate. This indicates that the degree of the stress concentration and unloading in the floor rock mass decreased after RHF, namely, the lower mining disturbance intensity.

As shown in Figures 6a and 7a, since there are few microseismic devices in the nonfractured section ( $0-50 \mathrm{~m}$ away from the cutout) and the floor failure depth cannot be clearly determined, the borehole observation mining fracture method was selected for supplementary detection in the section without RHF to evaluate the fracturing effect. The floor failure depth was detected in the section without RHF in panel 2129 using the borehole observation mining fracture method, as shown in Figure 14. This figure shows the measured results of the failure depth of the floor in the nonfractured roof section at panel 2129. The drilling peephole results indicate that the broken zones of the surrounding rock, fracture zone, soft rock, hard rock and interlayer alternate in the range of $0-45.7 \mathrm{~m}$ of the floor strata. The fracture zone and lateral fractures are still visible when the drilling depth is $45.7 \mathrm{~m}$. However, the rock layer at the borehole depth of $46-50 \mathrm{~m}$ is relatively intact. Excluding the influence of the soft rock and the quality of the hole formation, the results show that the failure depth of the floor is $45.7 \mathrm{~m}$, while the failure depth of the floor is approximately $30 \mathrm{~m}$ after roof fracturing based on microseismic monitoring results, which is $34.4 \%$ less than that of the zones without RHF. 

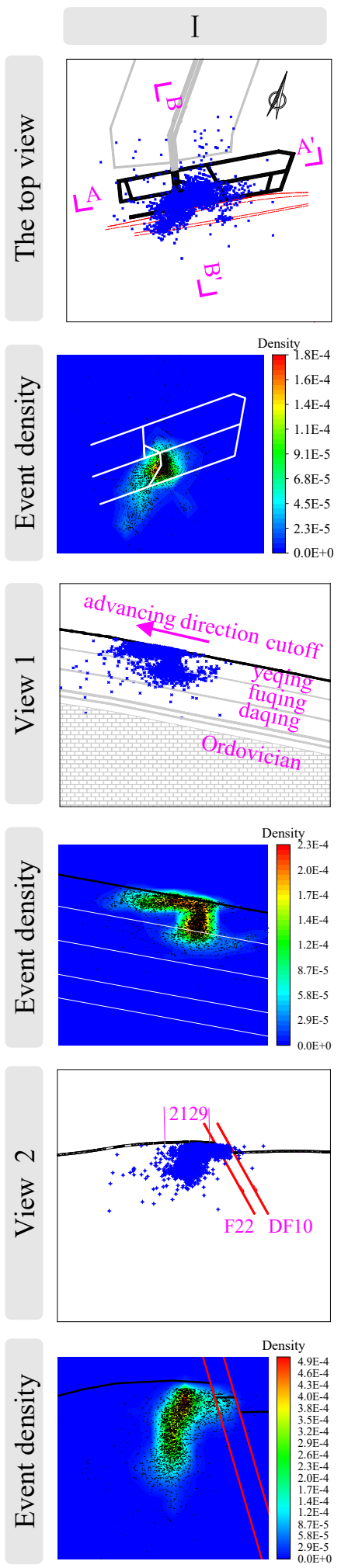
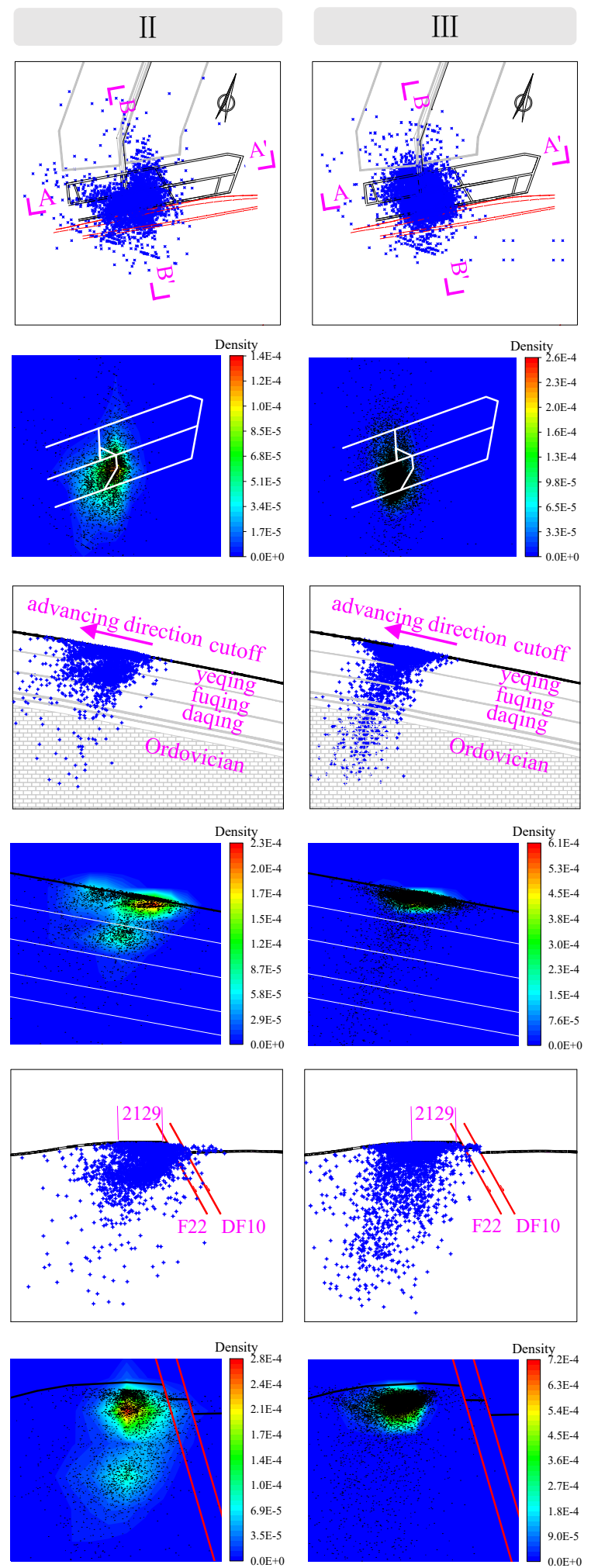
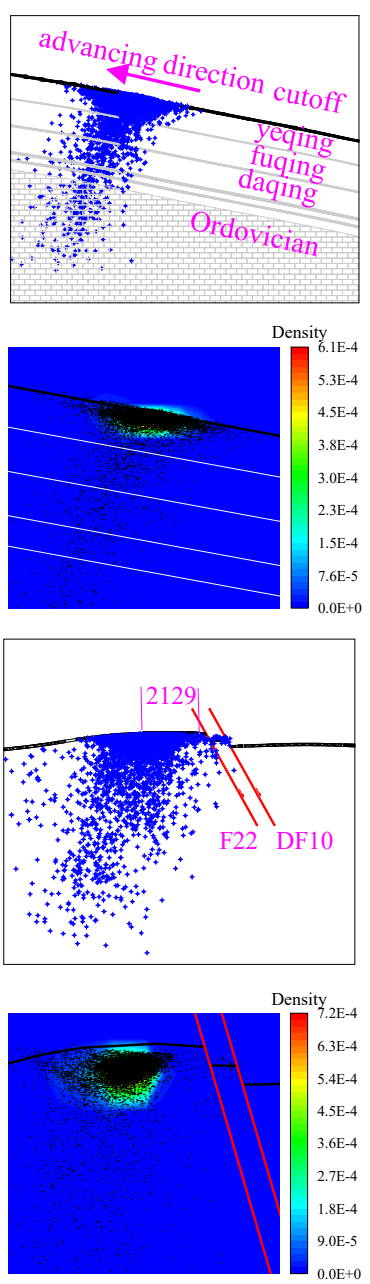
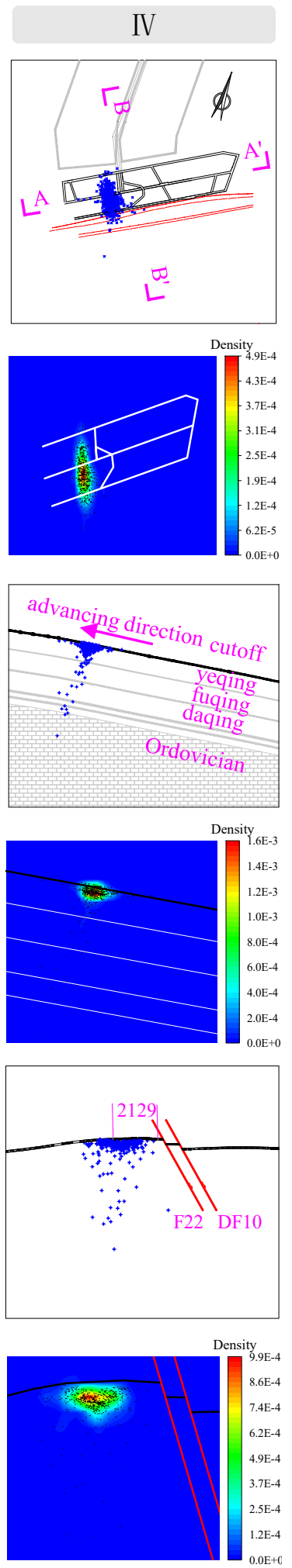

Figure 13. Development of seismic events. 

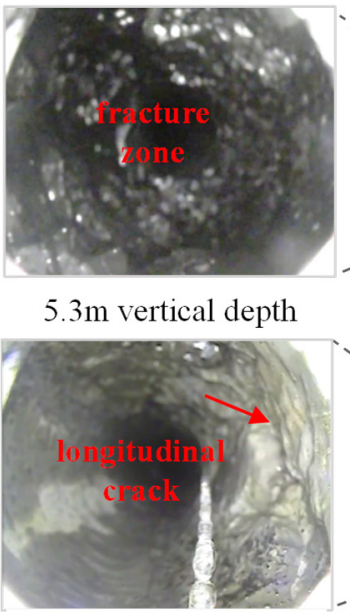

$24.9 \mathrm{~m}$ vertical depth

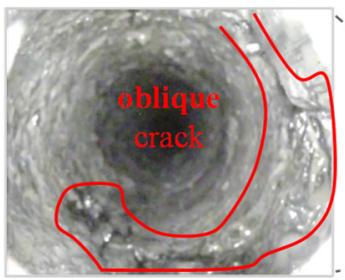

$45.7 \mathrm{~m}$ vertical depth

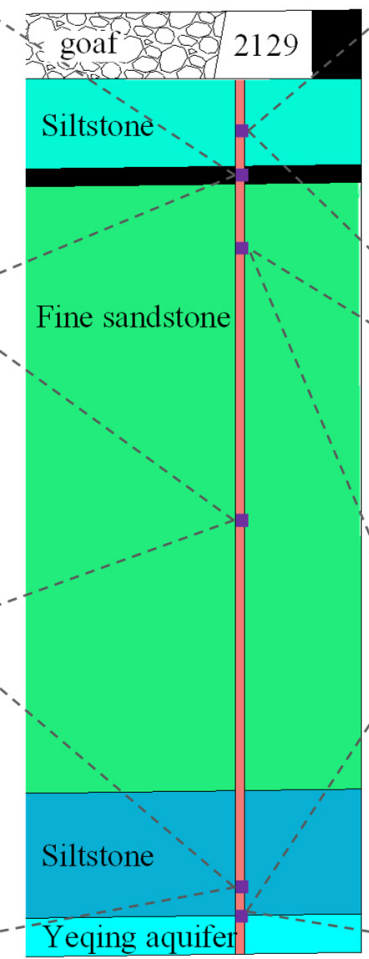

Yeqing aquifer

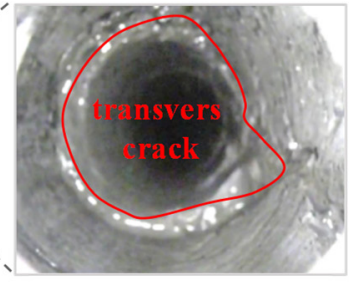

$2.7 \mathrm{~m}$ vertical depth

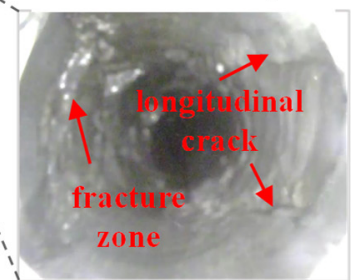

$9.4 \mathrm{~m}$ vertical depth

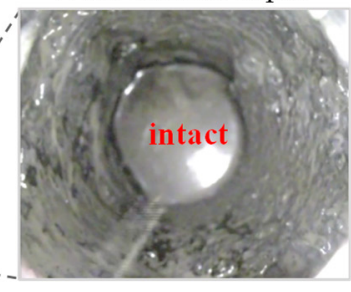

48.0m vertical depth

Figure 14. Floor failure depth measurement without roof hydraulic fracturing.

\subsection{Assessment of Water Inrush Risk}

Substituting the parameters of the 2129 working face before and after RHF into Equation (11), the Ordovician water pressure that the WRKS can tolerate before and after fracturing was calculated, as shown in Table 3. The floor failure depth of the 2129 working face before RHF was $45.7 \mathrm{~m}$. The thickness of the remaining intact aquifuges was only $1.41 \mathrm{~m}$, and the critical water pressure was $11.87 \mathrm{MPa}$. Hence, there was a high possibility of a floor water inrush. The critical water pressure after RHF was $15.11 \mathrm{MPa}$ when the unloading zone length was $93 \mathrm{~m}$, which was still higher than the water pressure of the Ordovician limestone aquifer (12.96 MPa) under the 2129 working face. According to the on-site monitoring of the mining stress, assuming that the length of the unloading zone was $40 \mathrm{~m}$ (equal to the four periodic weighting steps) after RHF, the calculated critical water pressure reached $19.52 \mathrm{MPa}$, which was higher than the actual water pressure by $6.56 \mathrm{MPa}$. The critical water pressure of the WRKS after RHF was greater than the actual water pressure of Ordovician limestone aquifer, and the working face was mined safely.

Table 3. Critical water pressure before and after RHF of panel 2129.

\begin{tabular}{cccccccc}
\hline RHF & $\boldsymbol{h}_{\mathbf{0}}(\mathbf{m})$ & $\boldsymbol{h}_{\mathbf{1}}(\mathbf{m})$ & $\boldsymbol{h}_{\mathbf{k}}(\mathbf{m})$ & $\boldsymbol{h}_{\mathbf{2}}(\mathbf{m})$ & $\mathbf{b}(\mathbf{m})$ & $\boldsymbol{a}(\mathbf{m})$ & $\boldsymbol{P}_{\boldsymbol{c 0}}(\mathbf{M P a})$ \\
\hline Before RHF & 15.8 & 45.7 & 1.41 & 129.01 & 93 & $40 / 93$ & $11.90 / 11.87$ \\
After RHF & 15.8 & 30 & 17.11 & 129.01 & 93 & $40 / 93$ & $19.52 / 15.11$ \\
\hline
\end{tabular}

\subsection{Mechanism of RHF to Prevent Floor Water Inrush}

The field monitoring results indicated that the floor failure depth decreased after RHF, and the cracks in the floor strata could not develop into a centralized water inrush channel. The corresponding mechanisms are presented as follows.

(1) The high abutment pressure induced by coal seam mining can generate high stress in the floor [46,50]. The cracks in the floor under the stress concentration area are deeply developed, which easily form a concentrated water-conducting channel [8]. 
RHF reduces the weighting step, the roof hanging distance and the magnitude of abutment pressure. Thus, the depth and intensity of the stress disturbance in the floor caused by the high abutment pressure are greatly decreased;

(2) The unloading range and degree of the floor in the goaf decreased after RHF. The floor strata in the unloading zone were loaded in time to shorten the unloading time. The unloading damage range decreased because the floor stress in the mined zone recovered in time. With the increasing load in the mined-out area, the ultimate water pressure that the WRKS can withstand increases, indicating that deformations and fractures can be compressed and closed by the collapsed roof rock, as described by Sun et al. [22];

(3) With the decrease in stress concentration and unloading degree in the floor, the floor failure depth decreased. The fractures in the floor did not extend to deep rock mass, resulting in a lower probability of conduction within the hydraulic fractures or hidden structures in the floor. The higher the stress in the floor of the mining area, the smaller the degree of unloading in the mining area, and the smaller the unloading failure depth of the floor [50,51].

Therefore, RHF essentially weakens the disturbance of mining on the floor stress field. Consequently, the stability of the WRKS is enhanced, and the expansion of the floor fissures is prevented; thus, the floor water inrush is controlled.

\subsection{Further Discussion and Implications}

In this study, we investigated the possibility of RHF to prevent floor water inrush. The results showed that the RHF shortened the weighting step and increased the load on the floor in the mining area, which enhanced the stability of the WRKS. Coal seam was mined safely at panel 2129 after roof hydraulic fracturing. Great economic benefits have been obtained. This finding is of great significance because it provides a reference to control water inrush from the coal seam floor after regional grouting treatment under strong mining disturbance and high water pressure. The prevention of water inrush from grouting reinforcement floor was generally to improve the grouting method, including increasing the grouting range [10], multi-level grouting [18] and adjusting the grouting parameters $[19,20]$. However, under high water pressure and strong mining disturbance, floor fractures initiated, or the original cracks activated. Therefore, this paper proposed the RHF method to prevent the activation and expansion of fractures in the floor from forming a "mining water inrush channel" based on the grouting reconstruction of the confined aquifer. In addition, the test face reduced the stress concentration of the isolated coal pillar using RHF. Although the RHF is not suitable for floor water inrush prevention under every geological condition, the method developed in this paper for reducing mining disturbance can be used in other mining areas. However, roof hydraulic fracturing can reduce the floor failure depth, but it cannot completely prevent floor water inrush due to the fact that floor water inrush is coupled with multiple factors. To completely prevent floor water inrush, comprehensive control should be carried out to control multiple influencing factors simultaneously.

\section{Conclusions}

A WRKS model of the floor in goaf was established to explore the mechanism of water inrush from the coal seam floor. Furthermore, a method of floor water inrush prevention was proposed, which was verified in panel 2129 in the Xingdong coal mine, Hebei Province, China, where there are complex hydrogeological conditions with five aquifers. The main conclusions drawn from the study are as follows.

(1) The mechanism of floor water inrush with multiple aquifers in deep mining is that the Ordovician limestone water connects with thin limestone water, and then the WRKS penetrates layer by layer. The uppermost WRKS is broken, and floor water inrush occurs. We found that reducing the mining stress could maintain the stability of the WRKS in the floor. Shortening the roof weighting step, reducing the unloading size of 
the goaf, decreasing the mining failure depth of the floor and increasing the thickness of the WRKS were suitable control measures. Therefore, RHF prevention technology was proposed;

(2) The average periodic weighting step was $9.53 \mathrm{~m}$ after RHF, which was $61.42 \%$ less than that of panel 2222 without RHF, adjacent to panel 2129. The maximum convergence rate of the roof to the floor in the hydraulic fracturing section was $75 \mathrm{~mm} / \mathrm{d}$. These results indicated that the disturbance of the surrounding rock caused by coal mining was significantly less than that of the working face without RHF. The floor failure depth was $30 \mathrm{~m}$ after RHF, which was $34.4 \%$ less than the section without RHF $(45.7 \mathrm{~m})$. The critical water pressure of the WRKS (15.11 MPa) exceeded the actual water pressure $(12.96 \mathrm{MPa})$ by $2.15 \mathrm{MPa}$ when the length of the unloading zone was $93 \mathrm{~m}$. The results revealed that the floor water-conducting channel was undeveloped due to the reduction in mining disturbance after RHF;

(3) This study demonstrates that comprehensive techniques to control floor water inrush are needed under complex geological conditions in deep mining. RHF is an optional method to prevent floor water inrush in deep mining, especially in complex geological and mining conditions such as hard roof, island working face and isolated coal pillar.

Author Contributions: Conceptualization, Y.J. and P.W.; methodology, Y.J. and P.W.; data curation, Q.R.; formal analysis, Y.J. and Q.R.; funding acquisition, Y.J.; writing-original draft, P.W.; writingreview and editing, Y.J. and Q.R.; project administration, Y.J. All authors have read and agreed to the published version of the manuscript.

Funding: This work was supported by the National Natural Science Foundation of China (Nos. U1910206, 51874312, 51861145403), Science and Technology Plant Project of Inner Mongolia Autonomous Region (2019GG140), Major Scientific and Technological Innovation Project of Shandong Province (Nos. 2019SDZY01, 2019SDZY02) and Beijing Municipal Natural Science Foundation (8184082).

Data Availability Statement: Not applicable.

Conflicts of Interest: The authors declare no conflict of interest.

\section{References}

1. Wu, Q.; Fan, S.; Zhou, W.; Liu, S. Application of the Analytic Hierarchy Process to Assessment of Water Inrush: A Case Study for the No. 17 Coal Seam in the Sanhejian Coal Mine, China. Mine Water Environ. 2013, 32, 229-238. [CrossRef]

2. $\mathrm{Wu}, \mathrm{Q}$.; Wang, M.; Wu, X. Investigations of groundwater bursting into coal mine seam floors from fault zones. Int. J. Rock Mech. Min. Sci. 2004, 41, 557-571. [CrossRef]

3. Adams, R.; Younger, P.L. A strategy for modeling ground water rebound in abandoned deep mine systems. Ground Water 2001, 39, 249-261. [CrossRef] [PubMed]

4. Zhao, Y.; Yang, T.; Zhang, P.; Xu, H.; Wang, S. Inversion of seepage channels based on mining-induced microseismic data. Int. J. Rock Mech. Min. Sci. 2020, 126, 104180. [CrossRef]

5. Dong, S.; Liu, Z.; Zheng, S.; Wang, H.; Shi, Z.; Shang, H.; Zhao, C.; Zheng, L. Technology and application of large curtain grouting water conservation mining based on macroscopic and mesoscopic characteristics of rock mass. J. China Coal Soc. 2020, 45, 1137-1149. (In Chinese) [CrossRef]

6. $\quad$ Li, H.; Bai, H.; Wu, J.; Ma, Z.; Ma, K.; Wu, G.; Du, Y.; He, S. A cascade disaster caused by geological and coupled hydro-mechanical factors-water inrush mechanism from karst collapse column under confining pressure. Energies 2017, 10, 1938. [CrossRef]

7. Xie, H.; Ju, Y.; Ren, S.; Gao, F.; Liu, J.; Zhu, Y. Theoretical and technological exploration of deep in situ fluidized coal mining. Front. Energy 2019, 13, 603-611. [CrossRef]

8. Li, C.; Zuo, J.; Wei, C.; Xu, X.; Zhou, Z.; Li, Y.; Zhang, Y. Fracture Development at Laminated Floor Layers Under Longwall Face in Deep Coal Mining. Nat. Resour. Res. 2020, 29, 3857-3871. [CrossRef]

9. Guo, J.; Ma, L.; Zhang, D. Management and Utilization of High-Pressure Floor-Confined Water in Deep Coal Mines. Mine Water Environ. 2019, 38, 780-797. [CrossRef]

10. Liu, S.; Fei, Y.; Xu, Y.; Huang, L.; Guo, W. Full-floor Grouting Reinforcement for Working Faces with Large Mining Heights and High Water Pressure: A Case Study in China. Mine Water Environ. 2020, 39, 268-279. [CrossRef]

11. Zhang, E.; Xu, Y.; Fei, Y.; Shen, X.; Zhao, L.; Huang, L. Influence of the dominant fracture and slurry viscosity on the slurry diffusion law in fractured aquifers. Int. J. Rock Mech. Min. Sci. 2021, 141, 104731. [CrossRef]

12. Huang, Z.; Jiang, Z.; Tang, X.; Wu, X.; Guo, D.; Yue, Z. In situ Measurement of Hydraulic Properties of the Fractured Zone of Coal Mines. Rock Mech. Rock Eng. 2016, 49, 603-609. [CrossRef] 
13. Meng, L.; Feng, Q.; Li, Q. Coupled simulation-optimization model for draining confined aquifer via underground boreholes to prevent water inrush of coal mines. Environ. Earth Sci. 2018, 77, 607. [CrossRef]

14. Mou, L.; Dong, S.; Zhou, W.; Wang, W.; Li, A.; Shi, Z. Data Analysis and Key Parameters of Typical Water Hazard Control Engineering in Coal Mines of China. Mine Water Environ. 2020, 39, 331-344. [CrossRef]

15. Zhao, Q.B. Ordovician limestone karst water disaster regional advanced governance technology study and application. Journal China Coal Soc. 2014, 39, 1112-1117. (In Chinese) [CrossRef]

16. Zhao, J.; Zhou, H.; Xue, D.; Su, T.; Deng, H.; Yang, H. Expansion law of seepage path in the concealed structural floor of coal seam in deep confined water. J. China Coal Soc. 2019, 44, 1836-1845. (In Chinese) [CrossRef]

17. Shimada, H.; Hamanaka, A.; Sasaoka, T.; Matsui, K. Behaviour of grouting material used for floor reinforcement in underground mines. Int. J. Min. Reclam. Environ. 2014, 28, 133-148. [CrossRef]

18. Yin, S.; Wang, Y.; Yin, H.; Xu, B.; Wang, T.; Yang, J.; Tian, W.; Xu, W.; Cao, M. Mechanism and full-time-space prevention and control technology of water inrush from Ordovician and thin limestone in deep mines. J. China Coal Soc. 2020, 45, 1855-1864. (In Chinese) [CrossRef]

19. Li, H.; Bai, H.; Wu, J.; Wang, C.; Ma, Z.; Du, Y.; Ma, K. Mechanism of water inrush driven by grouting and control measures-a case study of Chensilou mine, China. Arab. J. Geosci. 2017, 10, 1-10. [CrossRef]

20. Li, J. Water Inrush from Pregrouting Fractures Induced by Mining Activities and Its Engineering Control Method Optimization. Adv. Civ. Eng. 2019, 2019, 1-10. [CrossRef]

21. Li, C.; Zuo, J.; Shi, Y.; Wei, C.; Duan, Y.; Zhang, Y.; Yu, H. Deformation and fracture at floor area and the correlation with main roof breakage in deep longwall mining. Nat. Hazards 2021, 107, 1731-1755. [CrossRef]

22. Sun, J.; Hu, Y.; Zhao, G. Relationship between water inrush from coal seam floors and main roof weighting. Int. J. Min. Sci. Technol. 2017, 27, 873-881. [CrossRef]

23. Zhang, J. Investigations of water inrushes from aquifers under coal seams. Int. J. Rock Mech. Min. Sci. 2005, 42, 350-360. [CrossRef]

24. Guo, B.; Cheng, T.; Wang, L.; Luo, T.; Yang, X. Physical Simulation of Water Inrush through the Mine Floor from a Confined Aquifer. Mine Water Environ. 2018, 37, 577-585. [CrossRef]

25. Yu, S.; Xu, J.; Zhu, W.; Wang, S.; Liu, W. Development of a combined mining technique to protect the underground workspace above confined aquifer from water inrush disaster. Bull. Eng. Geol. Environ. 2020, 79, 3649-3666. [CrossRef]

26. Ren, Y.; Gao, H.; Xing, X. Research on Floor Failure Features of Coal Seam above the Confined Aquifer in the Case of Backfill Mining. IOP Conf. Ser. Earth Environ. Sci. 2018, 170, 22119. [CrossRef]

27. Kang, H.; Lv, H.; Gao, F.; Meng, X.; Feng, Y. Understanding mechanisms of destressing mining-induced stresses using hydraulic fracturing. Int. J. Coal Geol. 2018, 196, 19-28. [CrossRef]

28. Lu, Y.; Gong, T.; Xia, B.; Yu, B.; Huang, F. Target Stratum Determination of Surface Hydraulic Fracturing for Far-Field Hard Roof Control in Underground Extra-Thick Coal Extraction: A Case Study. Rock Mech. Rock Eng. 2019, 52, 2725-2740. [CrossRef]

29. Liu, J.; Liu, C.; Yao, Q.; Si, G. The position of hydraulic fracturing to initiate vertical fractures in hard hanging roof for stress relief. Int. J. Rock Mech. Min. Sci. 2020, 132, 104328. [CrossRef]

30. Huang, B.; Wang, Y.; Cao, S. Cavability control by hydraulic fracturing for top coal caving in hard thick coal seams. Int. J. Rock Mech. Min. Sci. 2015, 74, 45-57. [CrossRef]

31. Yin, S.; Xu, W.; Yin, H.; Cao, M. Study on risk assessment method of water inrush from thick floor aquifuge in deep mining. Coal Sci. Technol. 2020, 48, 83-89.

32. Wang, P.; Zhao, Y.; Jiang, Y.; Zhang, C.; Zhang, D.; Yang, J.; Liu, W.; Zhai, J. Characteristics and control technology of water inrush from deep coal seam floor above confined aquifer in Xingdong Coal Mine. J. China Coal Soc. 2020, 45, 2444-2454. (In Chinese) [CrossRef]

33. Li, B.Y. "Down Three Zones" in the prediction of the water inrush from coal bed floor aquifer theory, development and application. J. Shandong Min. Inst. 1999, 18, 11-18.

34. Odintsev, V.N.; Miletenko, N.A. Water inrush in mines as a consequence of spontaneous hydrofracture. J. Min. Sci. 2015, 51, 423-434. [CrossRef]

35. Qian, M.G.; Shi, P.W.; Xu, J.L. Mining Pressure and Strata Control; China University of mining and Technology Press: Xuzhou, China, 2010.

36. Miao, X.X.; Chen, R.H.; Bai, H.B. Fundamental concepts and mechanical analysis of water-resisting key strata in water-preserved mining. J. China Coal Soc. 2007, 32, 561-564. (In Chinese)

37. Miao, X.X.; Pu, H.; Bai, H.B. Principle of water-resisting key strata and its application in water-preserved mining. Zhongguo Kuangye Daxue Xuebao/J. China Univ. Min. Technol. 2008, 37, 1-4.

38. Shi, L.; Wang, Y.; Qiu, M.; Han, L.; Zhao, Y. Research on the required width of a fault waterproof coal pillar based on underground pressure control theory. Arab. J. Geosci. 2019, 12, 480. [CrossRef]

39. Yin, L.; Ma, K.; Chen, J.; Xue, Y.; Wang, Z.; Cui, B. Mechanical Model on Water Inrush Assessment Related to Deep Mining Above Multiple Aquifers. Mine Water Environ. 2019, 38, 827-836. [CrossRef]

40. Sun, J.; Wang, L.G.; Hou, H.Q. Research on water-isolating capacity of the compound water-resisting key strata in coal seam floor. Zhongguo Kuangye Daxue Xuebao/J. China Univ. Min. Technol. 2013, 42, 560-566. (In Chinese) [CrossRef]

41. Bai, Q.; Tu, S.; Wang, F.; Zhang, C. Field and numerical investigations of gateroad system failure induced by hard roofs in a longwall top coal caving face. Int. J. Coal Geol. 2017, 173, 176-199. [CrossRef] 
42. Liu, J.; Liu, C.; Li, X. Determination of fracture location of double-sided directional fracturing pressure relief for hard roof of large upper goaf-side coal pillars. Energy Explor. Exploit. 2020, 38, 111-136. [CrossRef]

43. Ma, S.; Chen, Y. Application of Hydraulic Fracturing and Energy-Absorption Rockbolts to Improve the Stability of a Gob-Side Roadway in a 10-m-Thick Coal Seam: Case Study. Int. J. Geomech. 2017, 17, 05017002. [CrossRef]

44. Wang, H.; Xue, S.; Jiang, Y.; Deng, D.; Shi, S.; Zhang, D. Field Investigation of a Roof Fall Accident and Large Roadway Deformation Under Geologically Complex Conditions in an Underground Coal Mine. Rock Mech. Rock Eng. 2018, 51, 1863-1883. [CrossRef]

45. Lin, X.; Wang, J.; Wang, C. Study on criterion method of water inrush from Ordovician Limestone water in underground mine. Coal Sci. Technol. 2015, 43, 126-130.

46. Zhou, J.R.; Yang, T.H.; Zhang, P.H.; Xu, T.; Wei, J. Formation process and mechanism of seepage channels around grout curtain from microseismic monitoring: A case study of Zhangmatun iron mine, China. Eng. Geol. 2017, 226, 301-315. [CrossRef]

47. Ma, K.; Sun, X.Y.; Tang, C.A.; Yuan, F.Z.; Wang, S.J.; Chen, T. Floor water inrush analysis based on mechanical failure characters and microseismic monitoring. Tunn. Undergr. Sp. Technol. 2021, 108. [CrossRef]

48. Cheng, G.; Tang, C.; Li, L.; Chuai, X.; Yang, T.; Wei, L. Micro-fracture Precursors of Water Flow Channels Induced by Coal Mining: A Case Study. Mine Water Environ. 2021, 40, 398-414. [CrossRef]

49. Zhou, X.; Ouyang, Z.; Zhou, R.; Ji, Z.; Yi, H.; Tang, Z.; Chang, B.; Yang, C.; Sun, B. An approach to dynamic disaster prevention in strong rock burst coal seam under multi-aquifers: A case study of tingnan coal mine. Energies 2021, 14, 7287. [CrossRef]

50. Liang, Z.; Song, W.; Liu, W. Theoretical models for simulating the failure range and stability of inclined floor strata induced by mining and hydraulic pressure. Int. J. Rock Mech. Min. Sci. 2020, 132, 104382. [CrossRef]

51. Yang, R.; Zhu, Y.; Li, Y.; Li, W.; Xiao, B. Stability analysis and control strategy of weakly cemented layered floor in mining affected roadway. J. China Coal Soc. 2020, 45, 2667-2680. (In Chinese) [CrossRef] 